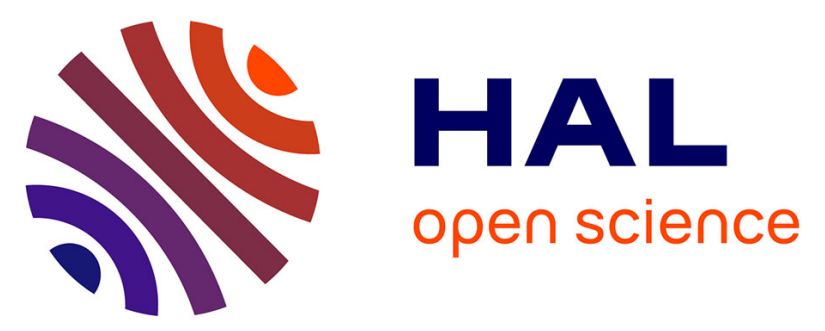

\title{
Multidisciplinary approach to reconstructing local pastoral activities: an example from the Pyrenean Mountains (Pays Basque)
}

Florence Mazier, Didier Galop, M.J. Gaillard, Christine Rendu, Carole Cugny, Amaïa Legaz, Odile Peyron, Alexandre Buttler

\section{To cite this version:}

Florence Mazier, Didier Galop, M.J. Gaillard, Christine Rendu, Carole Cugny, et al.. Multidisciplinary approach to reconstructing local pastoral activities: an example from the Pyrenean Mountains (Pays Basque). The Holocene, 2009, 19 (2), pp.171-188. 10.1177/0959683608098956 . halshs-00945594

\section{HAL Id: halshs-00945594 \\ https://shs.hal.science/halshs-00945594}

Submitted on 20 Mar 2014

HAL is a multi-disciplinary open access archive for the deposit and dissemination of scientific research documents, whether they are published or not. The documents may come from teaching and research institutions in France or abroad, or from public or private research centers.
L'archive ouverte pluridisciplinaire HAL, est destinée au dépôt et à la diffusion de documents scientifiques de niveau recherche, publiés ou non, émanant des établissements d'enseignement et de recherche français ou étrangers, des laboratoires publics ou privés. 


\section{The Holocene}

http://hol.sagepub.com

Multidisciplinary approach to reconstructing local pastoral activities: an example from the Pyrenean Mountains (Pays Basque)

F. Mazier, D. Galop, M.J. Gaillard, C. Rendu, C. Cugny, A. Legaz, O. Peyron and A. Buttler The Holocene 2009; $19 ; 171$

DOI: $10.1177 / 0959683608098956$

The online version of this article can be found at: http://hol.sagepub.com/cgi/content/abstract/19/2/171

Published by:

(S)SAGE

http://www.sagepublications.com

Additional services and information for The Holocene can be found at:

Email Alerts: http://hol.sagepub.com/cgi/alerts

Subscriptions: http://hol.sagepub.com/subscriptions

Reprints: http://www.sagepub.com/journalsReprints.nav

Permissions: http://www.sagepub.co.uk/journalsPermissions.nav

Citations http://hol.sagepub.com/cgi/content/refs/19/2/171 


\title{
Multidisciplinary approach to reconstructing local pastoral activities: an example from the Pyrenean Mountains (Pays Basque)
}

\author{
F. Mazier, ${ }^{1,2 *}$ D. Galop, ${ }^{3}$ M.J. Gaillard, ${ }^{1}$ C. Rendu, ${ }^{4}$ C. Cugny,${ }^{3}$ \\ A. Legaz, ${ }^{4}$ O. Peyron ${ }^{2}$ and A. Buttler ${ }^{5}$
}

('School of Pure and Applied Natural Sciences, Kalmar University, Barlastvägen 11, SE-391 82

Kalmar, Sweden; ${ }^{2}$ Laboratoire de Chrono-Ecologie, UMR 6565 CNRS, Université de Franche-Comté, 16 route de Gray, F-25030 Besançon Cedex, France; ${ }^{3}$ Laboratoire GEODE, UMR 5602, Université de Toulouse-Le Mirail, 5 allées A. Machado, F-31058 Toulouse Cedex, France; ${ }^{4}$ Laboratoire de France Méridionale et Espagne: histoire des Sociétés du Moyen Âge à l'Époque contemporaine (FRAMESPA), UMR 5136, Université de Toulouse-le-Mirail, Maison de la Recherche, 5 allées A.Machado, F-31058 Toulouse Cedex, France; ${ }^{5}$ Laboratoire des Systèmes écologiques - ECOS, Ecole polytechnique fédérale de Lausanne (EPFL) et Institut fédéral de recherches WSL, Antenne romande, Case postale 96, CH-1015 Lausanne, Switzerland)

Received 12 January 2008; revised manuscript accepted 10 June 2008

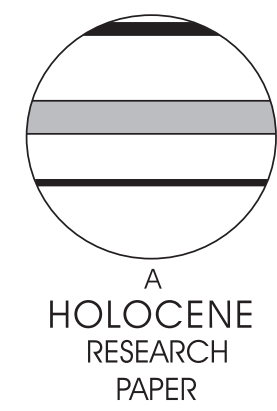

PAPER

\begin{abstract}
In this study archaeology, history and palaeoecology (modern and fossil data sets of pollen and nonpollen palynomorphs) were used to reconstruct small-scale pastoral activities in the Pyrenees Mountains during the last two millennia. Modern pollen assemblages from the major vegetation units (both natural and anthropogenic) are studied on one restricted watershed area. A correlative model (RDA) of 61 modern pollen spectra and 35 external variables distinguishes two groups of taxa, providing information on the nature and spatial extent of human impact on the landscape. The first pool indicates local pastoral activities, and the second one implies regional input from outside the studied watershed, and is not characteristic of a specific land use. These pools are described as 'Local Pastoral Pollen Indicators' (LPPI) for this particular mountain region on crystalline bedrock and 'Regional Human Activities Pollen Indicators' (RHAPI). The modern data set is used to aid interpretation of the local pollen sequence of Sourzay that covers the last 2000 calendar years BP, using RDA reconstructions, and best modern analogues as a means of comparing modern and fossil spectra. The study also demonstrates agreement between the independent interpretations of two fossil proxies, LPPI and coprophilous fungi.
\end{abstract}

Key words: Multiproxy approach, modern pollen-vegetation relationships, local pastoral pollen indicators (LPPI), past land use, western mountains Pyrenees.

\section{Introduction}

When attempting to reconstruct past human activities and their impact on vegetation and landscape, several fields of research should be combined, such as archaeology, history and palaeoecology (Berglund, 1991). Few reconstructions of past cultural landscapes combining all these disciplines have been attempted in

*Author for correspondence (e-mail: florence.mazier@hik.se, florence mazier@yahoo.fr) mountainous regions of southern Europe. The study presented in this paper was conducted within an interdisciplinary research program (Galop et al., 2004) aiming at using new approaches in palaeoecology and archaeology in order to reconstruct past human activities and related land-use and environmental dynamics in the Pyrenees Mountains.

In mountainous regions of southern Europe, agricultural activities are mainly based on grazing by large herbivores, principally cattle and sheep. Grazing is considered as the main biotic factor affecting ecosystem structure and dynamics in mountainous 


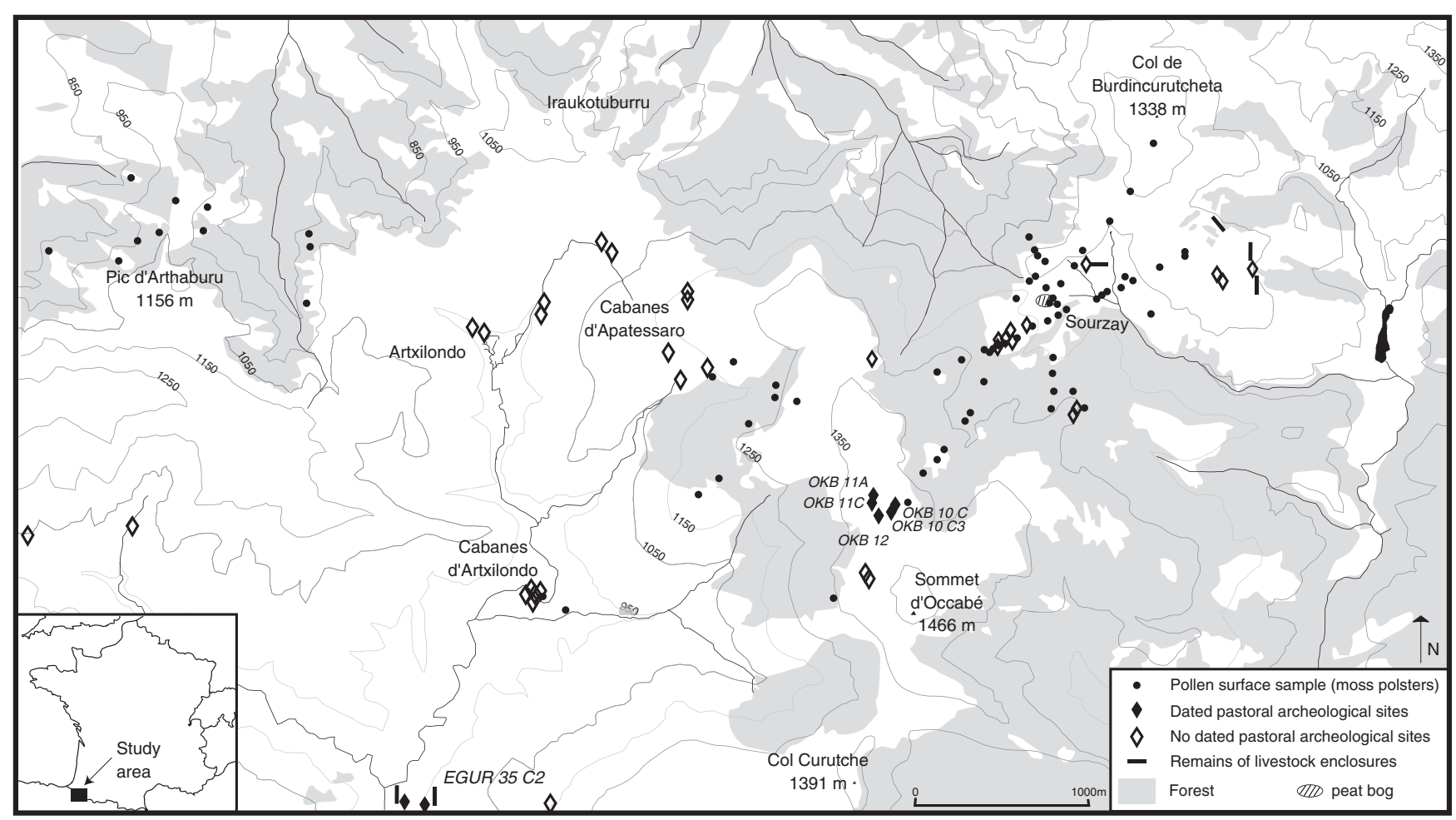

Figure 1 The study area of Iraty Mountains (Basque Country, southern France). The location of the 71 modern analogues (solid circles) where pollen samples (moss polsters) and related vegetation data were collected are shown. The modern analogues are located, in the vicinity of the fossil sequence (Sourzay peat bog), along four transects. Archaeological remains are also mentioned, with dated pastoral sites (solid diamonds) and other pastoral sites are not yet dated (open diamonds)

pastures at various spatial scales (Olff and Ritchie, 1998; Kohler et al., 2004). Land-use practices in the Iraty Mountains (Basque Country, western part of the Pyrenees) are based on traditional transhumance from the valley to the summer pastures. The main production system, ie, sheep raising for milk and cheese, necessitates small enclosures for gathering the herd, milking corridor, hut for cheese production and patches for summer pastures. The landscape is characterized today by a mosaic of vegetation types variously affected by pastoral activity (eg, extensive to intensive pastures, forested and open areas) (Mazier et al., 2006).

Long-term reconstruction of pastoral activities is a very complex task. Past pastoral activities involve the succession of pastoral practices, eg, extensive or/and intensive management, type of livestock, milk or meat production, which may be reflected in different landuse managements and spatial dynamics of local societies. In order to infer past environmental changes such as human impact on vegetation and landscapes, palynologists have commonly used the modern analogue approach, ie, have interpreted their data on the basis of modern-day observations and pollen-vegetation relationships. This approach encompasses both the indicator species approach (Iversen, 1964) and the comparative approach (Wright, 1967). The indicator species approach is still the most commonly used interpretation tool (Miras et al., 2004; Wehrli et al., 2007; Sjögren and Lamentowicz, 2008). The comparative approach implies the identification of modern pollen assemblages characteristics of different land-use patterns (meadow, cultivation, pastures ...) and the numerical comparison between modern and fossil pollen assemblages from comparable sedimentary environments (eg, lakes, mires). Valuable contributions of the comparative approach to the interpretation of pollen diagrams in terms of past human impact and land use are known mainly from the Nordic countries (Gaillard et al., 1992, 1994; Hjelle, 1999a; Räsänen, 2001). However, the pollen/vegetation/land-use relationships established for these regions are not necessarily valid in other areas, such as the mountains of Mediterranean Europe (Galop, 1998; Galop et al., 2003; Court-Picon et al., 2005, 2006; Mazier et al., 2006). Therefore, it was necessary to develop models of the modern pollen/environment relationship in the Pyrenees if fossil pollen sequences from the area were to be interpreted using the comparative approach. For this purpose, Mazier et al. (2006) collected surface pollen samples (moss polsters) in the watershed of a small topogenic peat bog that is selected here as the reference site for fossil pollen and non-pollen palynomorphs analysis. The peat bog is assumed to provide fossil pollen assemblages reflecting local variations in the vegetation composition (Bradshaw, 1981; Sugita, 1994) and, therefore, information on the nature and duration of local pastoral activities in the past. In parallel, data from archaeological excavations within and outside the watershed were collected in order to compare them with the fossil pollen and non-pollen palynomorph records (Rendu et al., 2004).

The aims of this study are (1) to establish whether various degrees of openness and grazing pressure produce significantly distinct modern pollen spectra, and to identify pollen taxa directly related to local pastoral activities, (2) to apply these results to fossil pollen records in order to derive more precise qualitative reconstruction of past land uses and pastoral landscapes, (3) to compare fossil pollen and non-pollen palynomorphs signals indicating local pastoral activities, and (4) to combine pollen and non-pollen palynomorph data with historical and archaeological information in order to identify local changes within the landscape and humaninduced vegetation, and to attempt to separate local and regional human impact in the study area. The ultimate goal is to better understand the relationships between human societies/economies and the landscape during the last two millennia. 


\section{Methods}

\section{Modern data set}

The modern data set includes 71 sites distributed in the woodland pastures of the Iraty Moutains (southern France) between 700 and $1500 \mathrm{~m}$ a.s.l. A preferential design was chosen to collect the modern pollen samples and related vegetation data. The stratification was based on the degree of landscape openness and current land use along four axes across the watershed and centred on the peat bog (Figure 1). In that way, the major relevant vegetation communities were sampled; however, because grazed oak forests and enclosures do not occur in the watershed, these vegetation types had to be collected (together with moss polsters for pollen) outside the watershed.

\section{Vegetation types and main description}

The vegetation was surveyed by means of the synusial integrated method, a tool making it possible to record the structure and patchiness of the pastoral phytoceonoses (Gillet et al., 1991, 2002; Gillet and Gallandat, 1996). This method is based on the BraunBlanquet approach (Braun-Blanquet, 1964), but allows better structural description and characterization of plant communities in their landscape context. The synusial integrated method, the vegetation survey and the classification of vegetation types are described in detail in Mazier et al. (2006).

A total of 71 vegetation inventories $\left(100 \mathrm{~m}^{2}\right)$ were classified into 13 vegetation communities, ie, cattle enclosure, overgrazed lawn, overtrampled lawn, grazed wet vegetation, mire vegetation, heathland, encroached heathland, fern fallow, open beech forest, semi-open beech forest, dense beech forest, semi-open oak forest, and fir-beech forest.

Here, we describe briefly the relevant vegetation communities for our purpose (vegetation types found as the best vegetation communities in the past). Overgrown lawn is dependent on the daily routine of livestock, mainly sheep, and presents a high pastoral value. This overgrazed community is a mosaic of two main vegetation patches induced by intense livestock activity (areas of urination, defecation and grazing). Overtrampled lawn is a nitrophilous community of poor pastoral value comprising a dominant vegetation patch characterized by intense trampling from wild animals or domesticated livestock. It is characterized by tracks and/or damaged soil. Grazed wet vegetation presents two main vegetation patches. The first, sparse cover of short herbs, is linked to trampling by domesticated livestock. The other patch is composed of wetland species such as Juncus effusus. Heathland is one of the dominant open vegetation types with encroached heathland. It is characterized by low pastoral pressure from sheep. Encroached heathland covers large areas of dry mountain slope; its species composition is very similar to that of heathland and results from the colonization by Ulex europaeus and Pteridium aquilinum, which is related to a decrease in grazing pressure. Three types of beech forests are characterized by various degrees of openness and cover of shrubs and herbs. The first two beech forests, open and semi-open, are partly used by livestock (sheep and horses), whereas the dense forest is rarely frequented by livestock

\section{Pollen data and environmental variables}

Details of the methods used are found in Mazier et al. (2006). We briefly summarize here the major points. The moss polsters for the pollen analysis and soil samples for soil chemistry were collected according to Gaillard et al. (1992). At each site and in the middle of the vegetation survey, up to ten moss polsters were sampled down to the soil surface and amalgamated in one composite sample. Field work was performed in September 2002 at the end of the flowering season to ensure that at least one complete season of pollen rain was included in moss polsters. Three soil samples $(0-10 \mathrm{~cm})$ were collected inside the area surveyed for vegetation and amalgamated into one sample for measurement of $\mathrm{pH}$ (KCL), $\mathrm{pH}\left(\mathrm{H}_{2} 0\right)$, organic matter, total $\mathrm{N}$ and volumetric water content at saturation. Altogether, 37 environmental variables including vegetation type, land use, soil, geological and geomorphological characteristics, were recorded for the 71 pollen samples (Mazier et al., 2006). Land-use variables included the livestock type as well as grazing pressure, amount of dung and trampling measured as ordinal variables (Mazier et al., 2006).

For analysis, pollen and spores were prepared following standard methods (Faegri and Iversen, 1989). Pollen identifications were made down to the lowest possible taxonomical level, using pollen keys (Faegri and Iversen, 1989; Moore et al., 1991; Reille, 1992-1998). A minimum of 400 pollen grains from terrestrial plants was counted per sample, and a total of 111 pollen and spore taxa were recorded. For numerical analysis, the pollen sum was reduced to the 85 pollen types from the plants included in the flora of the Iraty Mountains. Aquatic, hygrophilous plants, fern spores and pollen types from taxa from outside the region were excluded from the pollen sum.

Table 1 AMS radiocarbon dates from the Sourzay's peat record and archaeological sites

\begin{tabular}{|c|c|c|c|c|c|}
\hline Core/site & $\begin{array}{l}\text { Depth } \\
(\mathrm{cm})\end{array}$ & $\begin{array}{l}\text { Radiocarbon date } \\
\text { (yr BP) }\end{array}$ & $\begin{array}{c}\text { Calibrated age }(2 \sigma) \\
\quad(\text { cal. yr BP })\end{array}$ & $\begin{array}{l}\text { Calibrated age }(2 \sigma) \\
\quad(\text { cal. yr AD) }\end{array}$ & Laboratory reference \\
\hline \multicolumn{6}{|l|}{ Sourzay peatbog } \\
\hline & $11-13$ & modern & - & - & Vera-2552 \\
\hline & $18.5-19.5$ & $180 \pm 30$ & $-2(\mathbf{1 8 0}) 297$ & AD 1653 (1771) 1952 & Poz-13477 \\
\hline & 27 & $300 \pm 30$ & 296 (387) 461 & AD 1489 (1564) 1654 & Poz-6340 \\
\hline & $31-32$ & $400 \pm 35$ & 319 (467) 515 & AD 1435 (1484) 1631 & Vera-2553 \\
\hline & 39 & $755 \pm 30$ & 666 (689) 729 & AD 121 (1262) 1284 & Poz-13478 \\
\hline & $54-56$ & $1980 \pm 40$ & $1826(\mathbf{1 9 3 1}) 2036$ & $87 \mathrm{BC}(\mathrm{AD} 19) \mathrm{AD} 124$ & Beta-167161 \\
\hline \multicolumn{6}{|l|}{ Pastoral sites } \\
\hline OKB $10 \mathrm{C} 3$ & - & $1965+35$ & 1828 (1917) 1992 & $43 \mathrm{BC}(\mathrm{AD} 34) \mathrm{AD} 122$ & Ly-11253 \\
\hline OKB 10C & - & $140+40$ & $-3(\mathbf{1 4 2}) 282$ & AD 1668 (1809) 1953 & Beta-172184 \\
\hline OKB 11A & - & $790+45$ & $667(714) 786$ & AD 1164 (1237) 1283 & Ly-11254 \\
\hline OKB $11 \mathrm{C}$ & - & $745+40$ & $570(\mathbf{6 8 6}) 737$ & AD $1213(1265) 1380$ & Ly-11255 \\
\hline OKB 12 & - & $1420+30$ & $1290(\mathbf{1 3 2 3}) 1369$ & AD $581(628) 660$ & Vera- 2587 \\
\hline EGUR 35 C2 & - & $130+35$ & -3 (130) 279 & AD $1671(1821) 1953$ & Vera-2586 \\
\hline
\end{tabular}

Each calibrated radiocarbon date (in parentheses) is presented as a median probability, which is considered to be a robust statistical value (Telford et al., 2004), and its 2 sigma interval. The calibrated dates BP (in bold) were used to establish the timescale in the synthetic diagram of Figure 8 . 


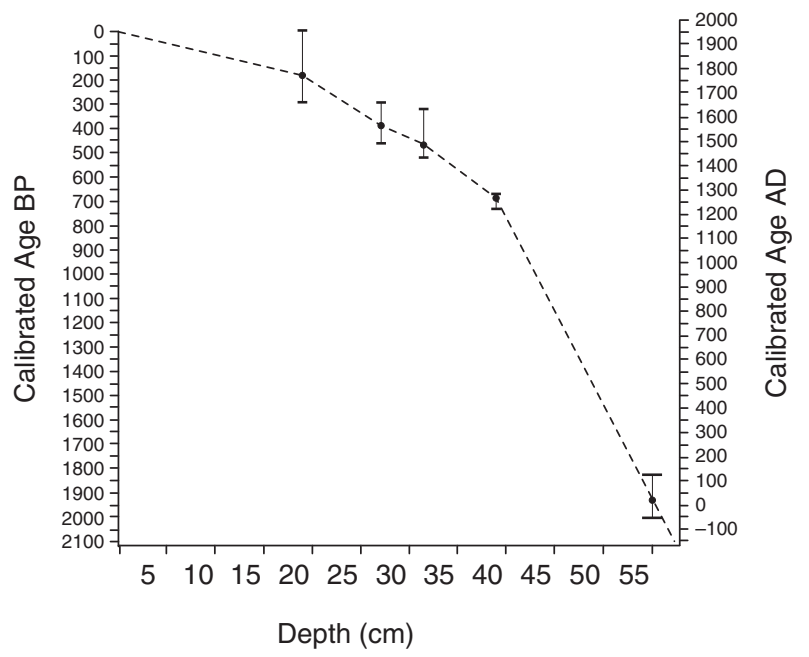

Figure 2 Depth-age model based on radiocarbon dates of terrestrial macrofossils. Maximum probability intervals and median probability (dots) are shown (see text for more information)

\section{Fossil data set - pollen and non-pollen palynomorphs}

The small peat bog of Sourzay $\left(43^{\circ} 02^{\prime} 54^{\prime \prime} \mathrm{N}, 1^{\circ} 05^{\prime} 50^{\prime \prime} \mathrm{E}, 1130 \mathrm{~m}\right.$ a.s.1.) ( $\leq 2 \mathrm{ha}$ ) was selected to perform pollen and non pollen palynomorph analyses, and to apply the comparative approach using the modern pollen-vegetation data set. The peat bog is treeless today and the mire vegetation is dominated by Eriophorum angustifolium, Juncus acutiflorus, Molinia caerulea ssp. caerulea, Erica tetralix and Calluna vulgaris (Mazier et al., 2006).

A total of 27 peat samples were taken at $2 \mathrm{~cm}$ intervals, except for the top of the core ( 1 and $3 \mathrm{~cm}$ intervals), and prepared using standard pollen preparation techniques (Faegri and Iversen, 1989). The level of pollen identification was harmonized as far as possible with that used in the modern pollen data set. Non-pollen palynomorphs were identified using the nomenclature proposed by van Geel (eg, van Geel, 1978) and are expressed as percentages of the total pollen sum.

Six peat samples were ${ }^{14} \mathrm{C}$ dated using the AMS technique. The ${ }^{14} \mathrm{C}$ dates were calibrated using CALIB 5.1 (Stuiver et al., 1998) software that uses the most updated data set (the INTCAL04 curve; Reimer et al., 2004) (Table 1). Figure 2 shows the depth-age model established for Sourzay's core taking into account the maximum probability intervals at 2 sigma ranges. Calibrated radiocarbon dates used to graph the synthetic diagram (see Figure 8) are mentioned as their median probability (Telford et al., 2004). Thus, the peat sequence appears to document the last two millennia.

\section{Archaeological pastoral sites}

The identification of archaeological sites occupied by pastoralists is not always straightforward. Many pastoral sites preserve only a few features and it is therefore difficult to assign the sites to a specific animal husbandry (ie, cattle, sheep or horse breeding) and to relate this information to spatial dynamics of local societies. Excavations of pastoral sites (Figure 1) combined with micromorphology and ethnoarchaeology approaches have been performed around the selected peat bog and published by Rendu et al. (2004).

The archaeological evidence of past human activities are mainly pastoral huts and enclosures dated by AMS to a time span ranging from $c . \mathrm{AD} 250$ to the modern period.

\section{Results and interpretation}

\section{Pollen analysis}

In this section, we briefly describe the main trends in the pollen data (Figure 3), and their interpretation based on the traditional indicator species approach (Iversen, 1964). The indicator value of pollen taxa follows Behre (1981), Gaillard (2007) and general knowledge on the modern flora and plant ecology of the study area (Galop, unpublished data, 1998). This is done in order to emphasize the contributions of the comparative and multiproxy approaches to the final interpretation of the pollen diagram later in the text. The indicator species approach is difficult to use to separate, eg, the impact of grazing from that of cultivation, as several ruderal plants such as Artemisia, Chenopodiaceae, Plantago spp., Rumex spp., Cichorioideae and Asteroideae might be representative of both grazing and arable land. We know that crop cultivation never occurred at the altitude of the study site. However, the pollen site also records vegetation changes at lower altitudes through long-distance pollen transport. Therefore, when pollen of ruderals appear or increase at the same time as pollen of cereals, we usually assume that part of the ruderals is coming from lower altitudes (see detailed interpretations below).

In the pollen diagram, aquatic, fern spores and hygrophilous plants (including Cyperaceae) were excluded from the pollen sum. The pollen assemblage zones (PAZ) were defined using a stratigraphically constrained numerical analysis (Figure 3), CONISS (Grimm, 1987). In the text below, we use the following abbreviations: P, pollen; AP, arboreal pollen; NAP, non-arboreal pollen; T, total pollen.

\section{PAZ-1 (57-38 cm): c. 100 BC-AD 1300}

This zone is characterized by less than $50 \%$ AP, Fagus, relatively constant values of Quercus and Corylus, and irregular values of Alnus. Common herbs are Poaceae, Cyperaceae and Apiaceae. Calluna, Asteroideae, Cichorioideae, Cirsium-type, Rubiaceae cf. Galium, Artemisia, Plantago spp., Brassicaceae, and Scabiosa are all represented regularly through the zone. Sphagnum has its highest values for the profile in this zone. The zone boundary PAZ $1 /$ PAZ 2 is characterized primarily by an increase in percentages of Fagus, Cyperaceae and Cichorioideae, and a decrease in percentages of Corylus, Poaceae and Calluna.

Interpretation: relatively open vegetation dominated by herb communities with grasses and indicators of fresh to humid (Cirsium type, Cyperaceae, Scabiosa) and dry (Asteroideae, Cichorioidae, Artemisia, Plantago spp.) grasslands. The occurrence of Calluna, Rubiaceae cf. Galium and several of the herb taxa mentioned above may also represent Calluna heaths or local bog vegetation (see interpretation of PAZ 2 below). Whether ruderals such as Artemisia, Asteraceae, Cichorioideae are coming from the local grasslands and ruderal lands or from lower altitudes remains an open question. Fagus was probably dominant among trees, but light-demanding species (Betula, Corylus) were relatively common, which may suggest a landscape dominated by open and semi-open grasslands (grazed).

\section{PAZ $2(38-30 \mathrm{~cm}):$ c. AD $1300-1500$}

As PAZ 1, this zone is characterized by AP less than 50\%. Fagus is dominant among trees. Quercus and Corylus show relatively constant values. Poaceae is still important. Calluna has low values and Cyperaceae and Cichorioideae have their highest values in this zone. Rumex spp. reaches its highest values in the profile. There are regular occurrences of Cerealia and Juglans. The zone boundary PAZ 2/PAZ 3 is characterized primarily by an increase in percentages of Pinus, Abies, Rumex spp. and Pteridium, and a decrease in percentages of Poaceae, Cyperaceae, Apiaceae and 


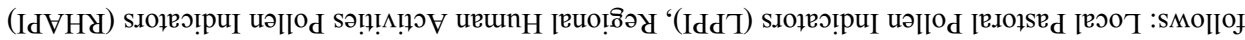

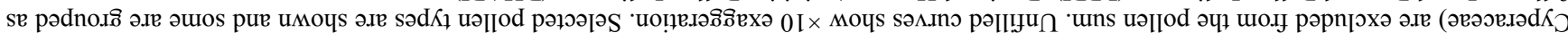

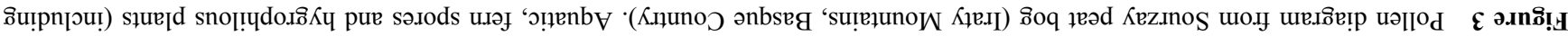

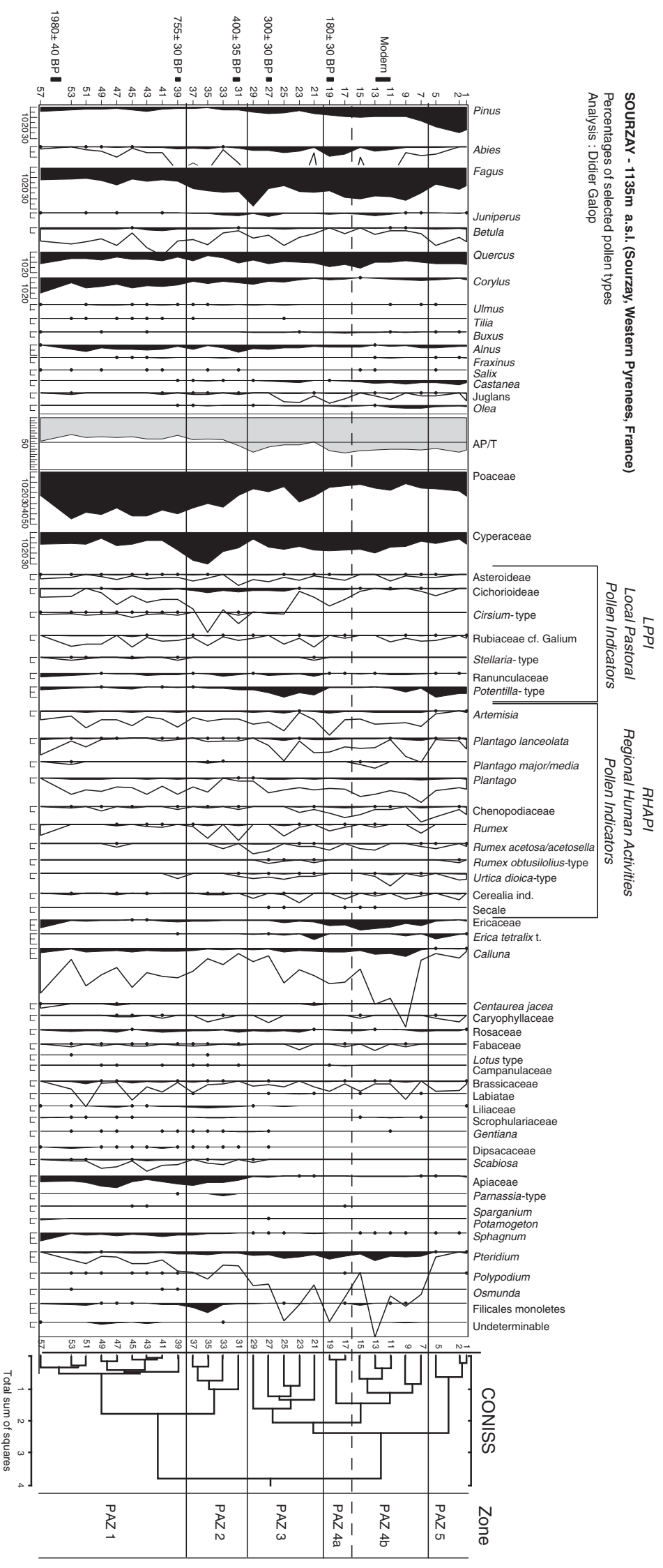




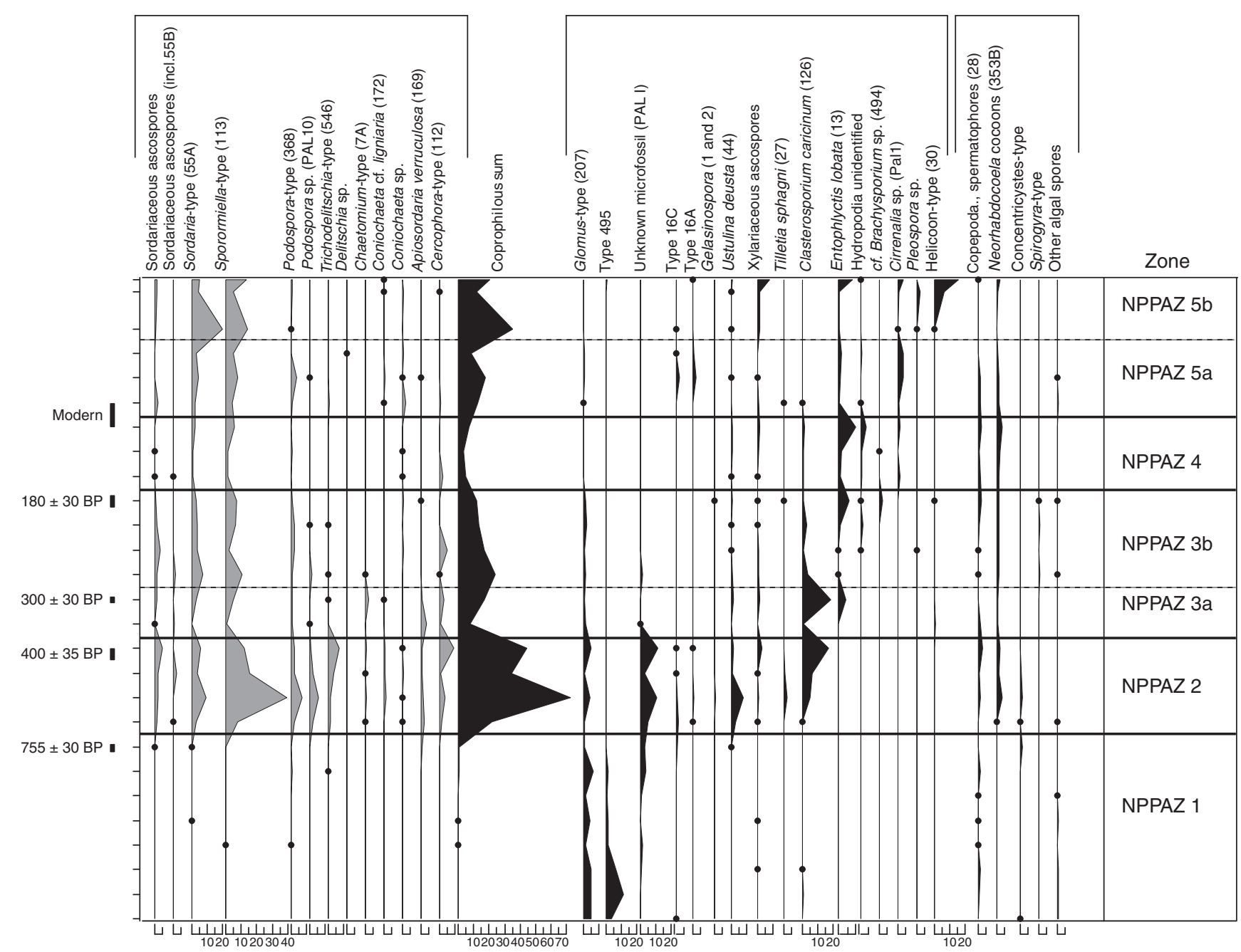

$1980 \pm 40 \mathrm{BP}$

Figure 4 Non-pollen palynomorphs diagram from Sourzay peat bog (Iraty Mountains, Basque Country). The non-pollen palynomorphs (NPP) are expressed as percentages of total pollen sum. Selected NPP types are shown and grouped as follows: Coprophilous fungi (ascospores), other fungal remains, algal and zoological types

Scabiosa. Sphagnum decreases through the zone to very low values.

Interpretation: transition period from a relatively open landscape (with Poaceae, Rubiaceae cf. Galium, Brassicaceae and light-demanding trees such as Betula and Corylus) to a gradually more wooded landscape where beech Fagus and Abies expand. The progressive decrease in Poaceae, Brassicaceae, Cirsium type, Scabiosa, Apiaceae, Rubiaceae cf. Galium, Calluna and Sphagnum is difficult to interpret. These taxa may have been related to fresh or dry grasslands (and Calluna heaths), and/or may have grown locally at the coring site. A possible interpretation of the change between PAZ 1 and 2 would be a decrease in grazing (abandonment) and subsequent overgrowing by trees (Fagus, Abies), shrubs (Juniperus) and Pteridium. The increase in Asteroideae, Cichorioideae, Cirsium type, Rumex spp. and the regular findings of Cerealia and Juglans might indicate the occurrence of cultivation and ruderal land in the region, probably at lower altitudes. On the other hand, an increase in percentages of Asteroideae, Cichorioideae, Cirsium type and Chenopodiaceae could be due to more intensive grazing activities locally, and therefore a better representation of ruderal taxa. We assume that the decrease in Sphagnum and simultaneous increase in
Cyperaceae are due to local changes towards drier conditions at the bog site.

\section{PAZ 3 (30-20 cm): c. AD 1500-1750}

AP reaches percentages slightly $>50 \%$ and is dominated by Fagus, Quercus, Pinus and Abies. Betula, Corylus and Alnus decrease through the zone to reach very low values. Poaceae and Cyperaceae are still dominant among herbs. Rubiaceae cf. Galium and Calluna regain values similar to those found in PAZ 1, together with high values of Potentilla type. Note the regular occurrence of Erica tetralix type. Other herbs become more common than earlier, ie, Plantago lanceolata, Rumex acetosa/acetosella, Rumex obtusifolius type, Urtica dioica type and Cerealia (with first occurrences of Secale). The values of Pteridium increase significantly. The boundary PAZ 3/PAZ 4 is characterized by decreases in Poaceae, Rubiaceae cf. Galium, Potentilla type and an increase in Ericaceae.

Interpretation: shade-tolerant trees species (Fagus, Abies) and Quercus are probably the major trees represented in the area, while pioneer tree species (Corylus and Betula) are less common than earlier. The high values of Potentilla type and Ericaceae, and the occurrence of Erica tetralix type, might indicate drier conditions 
Table 2 Forward selection of explanatory variables

\begin{tabular}{ll}
\hline $\begin{array}{l}\text { Forward selection and Monte Carlo } \\
\text { permutation tests (999 permutations) }\end{array}$ & $P$ value \\
\hline Quantitative variables & \\
North aspect (trigonometric scale) & 0.001 \\
pH (KCL) & 0.010 \\
Organic matter (\%) & 0.026 \\
Total N (\%) & 0.033 \\
Semi quantitative variables & \\
Trampling & 0.002 \\
Grazing & 0.008 \\
Nominal variables - vegetation communities & \\
Extensive pastures & 0.002 \\
Semi-intensive pastures & 0.011 \\
Grazed wet vegetation & 0.016 \\
Semi-open oak fores & 0.018 \\
Overgrazed community & 0.019 \\
Overtrampled community & 0.029 \\
Fern forest & 0.051 \\
\hline
\end{tabular}

Results of unrestricted Monte Carlo permutation tests (999 permutations) on the selected quantitative, semi-quantitative and nominal variables.

either locally at the coring site or in the area (ie, dry grassland). The gradual decrease in Alnus and very sporadic findings of Sphagnum also agree with this interpretation. An increase in human activities in the region is revealed by the regular occurrences of cereal pollen types and higher values of many ruderals. It is difficult to interpret the pollen assemblages in terms of grazing activities in the area. The lower values of Poaceae and high values of Pteridium may suggest that grazing pressure decreased, and that grasslands were partly overgrown by Pteridium. On the other hand, grazing may have occurred in Calluna heaths and drier grasslands.

\section{PAZ 4 (20-6 cm): c. AD 1750-1900}

AP is c. $60 \%$ through the entire zone, dominated by Fagus, Quercus and Pinus. Dominant herbs are Poaceae, Cyperaceae, Calluna and Ericaceae. Pteridium has a similar representation as in PAZ 3. Other common herb taxa are Plantago lanceolata, Plantago spp., Artemisia, Chenopodiaceae, Rumex spp. and Cerealia type. Two subzones can be differentiated: $4 \mathrm{a}(20-16 \mathrm{~cm})$ is characterized by relatively high values of Abies, Juglans, Artemisia, Cichoriodeae and Chenopodiaceae, while 4b (16-6 $\mathrm{cm}$ ) is characterized by higher values of Calluna and Ericaceae than earlier (highest values in the profile), and the first regular occurrence of Olea and Castanea. The boundary PAZ 4/PAZ 5 is characterized by an increase of Pinus, Betula, Potentilla type and a decrease of Fagus, Plantago lanceolata, Plantago spp., Ericaceae and Pteridium. Calluna decreases abruptly in the last part of the zone.

Interpretation: Fagus, Pinus and Quercus were the dominant trees in the area. Betula, Corylus and Alnus are now poorly represented, which may indicate a more intensive use of the grasslands for grazing, as well as generally drier soil conditions. The latter also agrees with high values of Calluna and Ericaceae, which may indicate an increase in the area of Calluna heaths or the development of Ericaceae (Calluna included) on the surface of the mire. In subzone $4 \mathrm{a}$, the representation of cereals and most ruderals is very similar to that of PAZ 3, which suggests that the site still registers cultivation activities in the region. Abies and Quercus are best represented during this period, which suggests that the tree cover was particularly high at that time. In subzone $4 \mathrm{~b}$, Calluna and other Ericaceae reach their best representation in the entire profile. This change together with a decrease in Quercus and Abies might indicate a renewed higher grazing pressure around the study site, opening of the landscape and the development of Calluna heaths. However, as earlier, Calluna and Ericaceae might belong to the local bog vegetation. Cereals and ruderals still indicate cultivation activities in the region. The more frequent findings of Castanea and Olea are due to regional long-distance pollen transport from areas where these two species were cultivated, on the northern (Castanea) and southern (Olea) slopes of the Pyrenees (Galop, 1998). The increases in percentages of Rubiaceae cf. Galium, Plantago lanceolata, Potentilla type in PAZ $4 \mathrm{~b}$ to similar levels than in PAZ 3 suggest that the local vegetation is regaining comparable characteristics to those of PAZ 3, ie, slightly higher grazing pressure. The decrease in Abies to very low values, followed by a decrease in Fagus would support this interpretation. However, the decreases in Fagus and Calluna might be due to a calculation artefact because of an increase in Pinus at lower altitudes.

\section{PAZ 5 (6-1 cm): c. AD 1900-2000}

AP $(>60 \%)$ is mostly represented by Pinus, Fagus, Betula and Quercus. Abies disappears. Dominant herbs are Poaceae and Potentilla type. Other common herbs are Cyperaceae, Erica tetralix, Plantago and Chenopodiaceae. Ericaceae, Calluna and Pteridium have very low values.

Interpretation: the low values of Abies, and the increases in Betula, Potentilla type and Erica tetralix type suggest that vegetation on the bog or in the area around it has very similar characteristics as during PAZ 3, ie, grazing pressure is higher than during PAZ 4, Abies (and perhaps Fagus) are less frequent and grazing land is expanding with the light-demanding Betula.

\section{Non-pollen palynomorphs analysis}

Several studies have established the indicative value of coprophilous fungi (Ascomycetes) in terms of grazing and human activities (Davis, 1987; Buurman et al., 1995; Hausmann et al., 2002; van Geel et al., 2003; Blackford and Innes, 2006; Davis and Shafer, 2006; Graf and Chmura, 2006; van Geel and Aptroot, 2006). Coprophilous fungi and other selected NPPs are presented (Figure 4). More detailed descriptions of the non-pollen palynomorphs assemblage zones (NPPAZ) and discussion of the NPP types included in the coprophilous groups will be published elsewhere (C. Cugny, F. Mazier and D. Galop, unpublished data, 2006).

\section{NPPAZ 1 (53-38 cm): c. AD 200-1300}

This zone is characterized by few and scattered findings of NPP, except for Glomus-type and Type 495 that are recorded regularly.

Interpretation: NPPs provide little information. The possible reason behind the rarity of findings will be published elsewhere (C. Cugny, F. Mazier and D. Galop, unpublished data, 2006).

\section{NPPAZ 2 (38-30 cm): c. AD 1300-1500}

This zone is characterized by an abrupt increase of fungal spores, especially coprophilous fungi represented by high values (35-70\%). The dominant types are Sporormiella (Type 113), Sordaria (Type 55A), Podospora (Type 368 and cf. P. polysporus), Trichodelitschia (Type 546) and Cercophora (Type 112). Other fungal types occurring regularly are Glomus type, unknown microfossil (PAL I), Ustulina deusta (Type 44) and Clasterosporium caricinum (Type 126). The zone boundary $1 / 2$ corresponds to a distinct decrease of these taxa.

Interpretation: high values of coprophilous fungi indicate local presence of herbivores and human activities. The increase of the percentages of Ustulina deusta may suggest that Fagus occurred locally in the surroundings of the peat bog. Clasterosporium caricinum probably reveals the local presence of Carex spp. on the peat bog. 


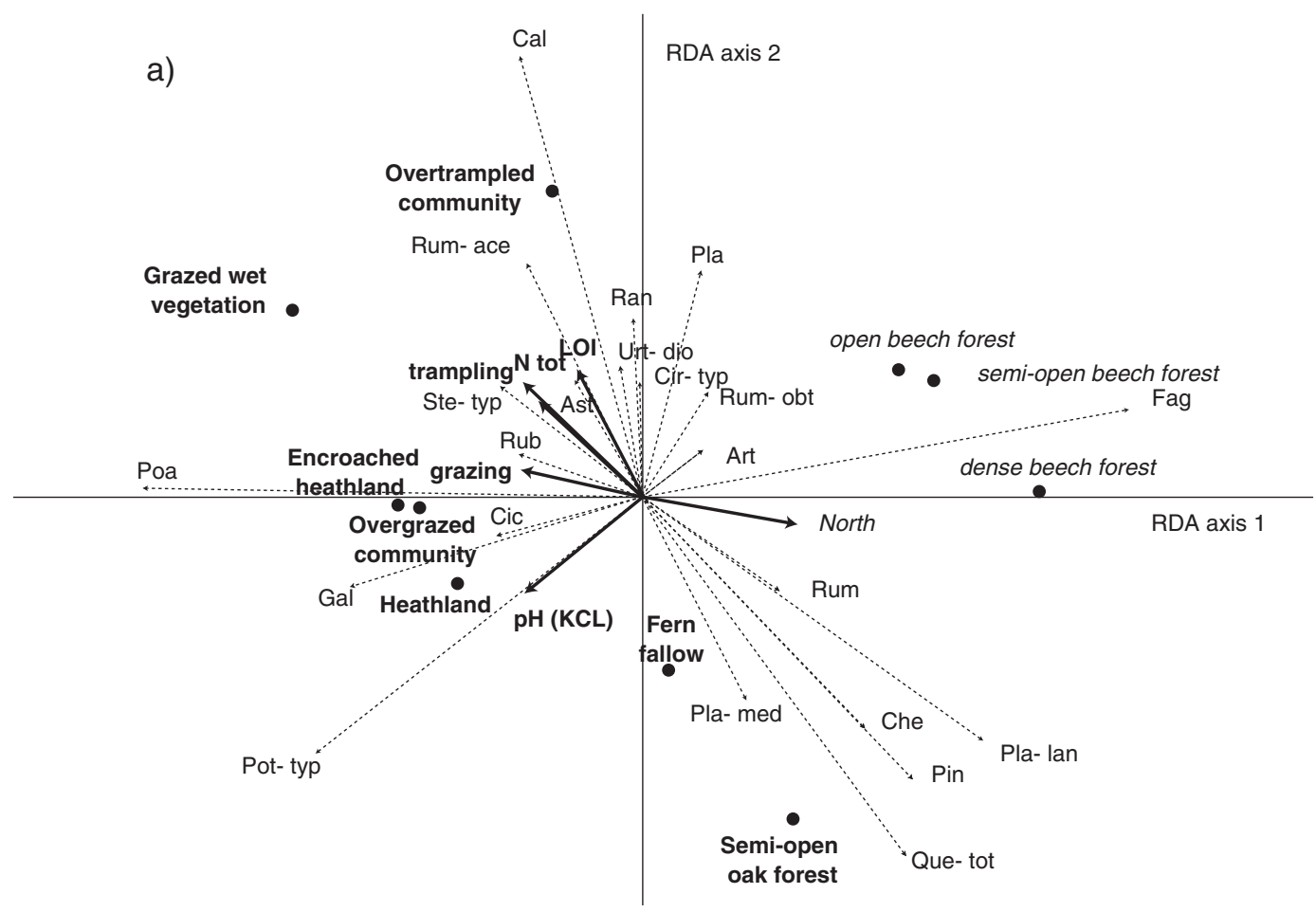

b)

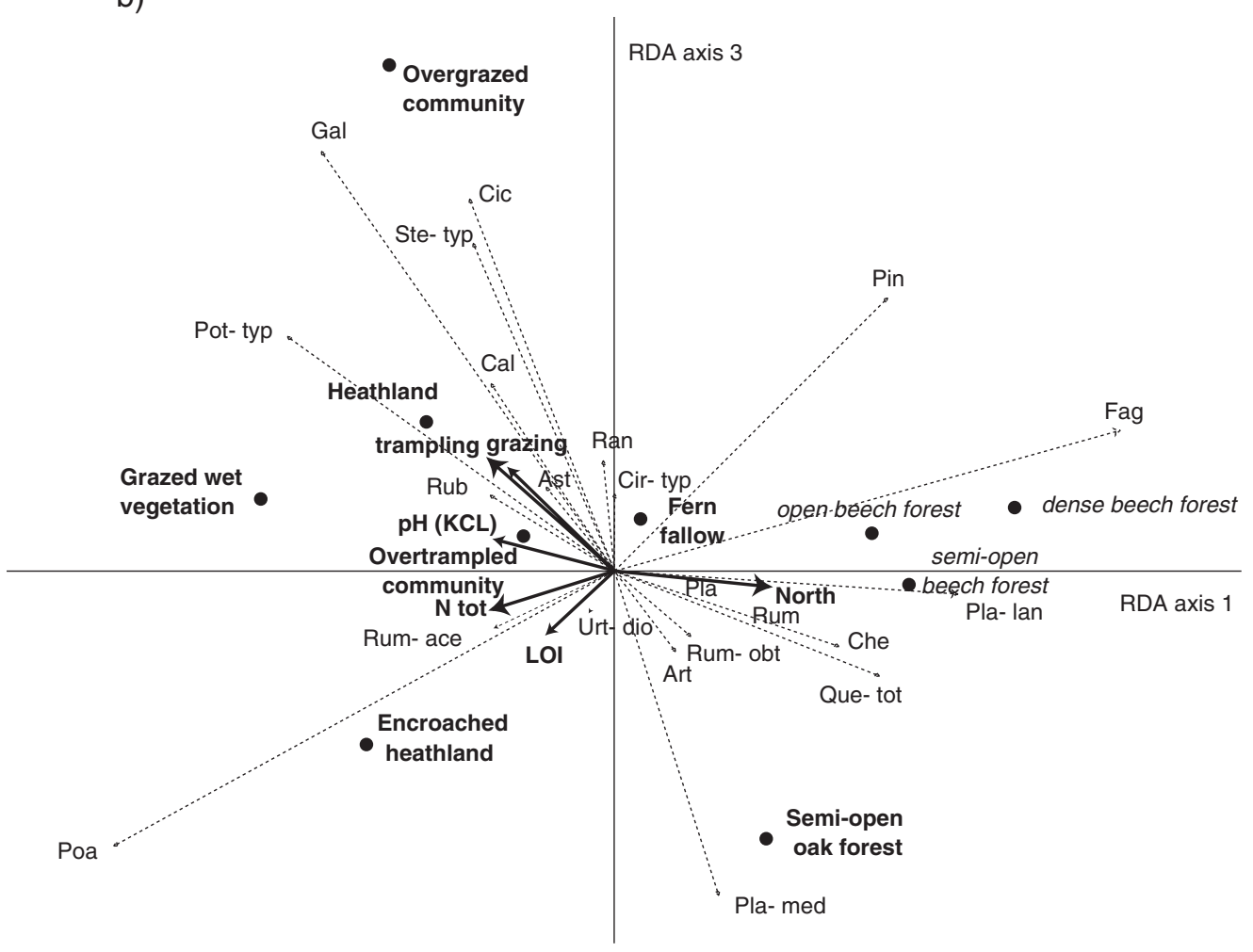

Figure 5 Redundancy analysis (RDA) of the modern pollen assemblages, using 13 explanatory variables (nominal variables are given with their centroïds (solid circles) and quantitative variables with solid arrows), four passive variables (italic) and selected taxa (doted arrows). The three first axes explain respectively $17.9,6.2$ and $5.4 \%$ of the total variation in the modern pollen data, and are all significant $(P<0.001$ after 999 permutations). LOI, loss on ignition. Abbreviations of selected taxa: Art, Artemisia; Ast, Asteroideae; Cal, Calluna; Che, Chenopodiceae; Cic, Cichoriodeae; Cir-typ, Cirsium type; Fag, Fagus; Gal, Galium type; Poa, Poaceae; Pla, Plantago; Pla-lan, Plantago lanceolata, Pla-med: Plantago major/media, Pin: Pinus, Que-tot: Quercus total, Pot-typ: Potentilla type; Ran, Ranunculaceae; Rub, Rubiaceae; Rum, Rumex; Rum-ace, Rumex acetosa/acetosella; Rum-obt, Rumex obtusifolius; Ste-typ, Stellaria type; Urt-dio, Urtica dioica. (a) Taxa scores and environmental variables on RDA axes 1 and 2. (b) Taxa scores and environmental variables on RDA axes 1 and 3

NPPAZ 3 (30-20 cm): c. AD 1500-1775

Coprophilous fungi (10-25\%) are mostly represented by Sordaria and Sporormiella types. Other common fungal types are Entophlyctis lobata (Type 13) and Clasterosporium caricinum. The latter, particularly well registered in the upper part of the zone, can be used to differentiate two subzones, NPPAZ 3a $(30-26 \mathrm{~cm})$ and NPPAZ $3 \mathrm{~b}(26-20 \mathrm{~cm})$. The zone boundary $3 / 4$ corresponds to a decrease of coprophilous fungi and Glomus type.

Interpretation: lower values of coprophilous fungi indicate that the surroundings of the peat bog were less intensively grazed than earlier. 
NPPAZ 4 (20-12 cm): c. AD 1775-1825

Coprophilous fungi have their lowest values for the profile in this zone (except for NPPAZ 1), while Entophlyctis lobata is more common than earlier. The zone boundary $4 / 5$ is characterized by a decrease of Entophlyctis lobata and an increase of Sordaria and Sporormiella types.

Interpretation: low values of coprophilous fungi, compared with the former periods, suggest an important decrease of grazing activities in the vicinities of the peat bog.

\section{NPPAZ 5 (12-1 cm): c. AD 1825-2000}

This zone is characterized by high proportions of coprophilous fungi $(10-35 \%)$ dominated by the Sordaria and Sporormiella types. Two subzones can be differentiated, ie, NAPPZ 5a (12-6 $\mathrm{cm})$ and NPPAZ $5 \mathrm{~b}(6-1 \mathrm{~cm})$; the latter has higher proportions of coprophilous fungi.

Interpretation: the increase in coprophilous fungi corresponds to an increase of local pastoral activities, especially in NPPAZ 5b.

\section{Numerical analysis}

Direct gradient analysis, ie, redundancy analysis (RDA), was considered appropriate to describe the major gradients in the modern pollen assemblages and to relate them to the environmental and anthropogenic variables (Mazier et al., 2006). On the basis of forward selection and Monte Carlo permutation tests (999 unrestricted permutations), 13 explanatory variables were retained for their significance (Table 2), ie, vegetation units (overgrazed lawn, overtrampled lawn, grazed wet vegetation, fern fallow, semi-open oak forest, heathland and encroached heathland,), pastoral variables (trampling and grazing) and other environmental variables (north aspect, $\mathrm{pH}(\mathrm{KCL})$, loss on ignition and total $\mathrm{N}$ ). Other remaining variables were included passively in the ordination diagrams, or given as covariables (pudding rock). Pollen percentages were $\log$-transformed $(\ln (a y+c)$ where $a=1$ and $c=1)$ and double-centred. More details of the statistical analyses are given by Mazier et al. (2006).

Twenty seven fossil pollen assemblages from the Sourzay peat bog were compared numerically with the modern pollen data set in two ways:

(1) the fossil samples were included passively in modern data RDA (Ter Braak and Prentice, 1988). The position (score) of fossil pollen samples was recalculated relative to the modern pollen assemblage on the basis of the entire pollen composition on the first three axes of the RDA (significant axes) and the relevant variables. These scores, by analogy with the modern pollen samples, provide information on the environmental characteristics of the fossil samples.

(2) In complement, the modern analogue technique (MAT) (Overpeck et al., 1985; Guiot, 1990) was used to match fossil pollen assemblages to the modern ones for which environmental parameters are known (ie, vegetation types, grazing pressure, etc.). A dissimilarity measure based on squared chord distance (SCD), identified in previous works as the best general metric for the MAT (Overpeck et al., 1985), was used to compare each pollen fossil assemblage with all modern pollen assemblages in order to determine whether two assemblages can be considered as 'analogues' or 'non-analogues' (Prentice, 1980; Overpeck et al., 1985). The threshold value, quantitative level of dissimilarity below which two samples are considered to have a reasonable match, depends on the modern data set, ie, the degree of variety in vegetation types and the pollen taxa diversity (Wahl, 2004). Calculation of the dissimilarity values was based on a selection of 44 common pollen types (41 types with percentage values $<0.5 \%$ in the modern pollen spectra were excluded). Because of the small size of the modern pollen data set (eg, the small number of samples per vegetation type), the five most similar modern spectra to each fossil spectrum are defined as best analogues under the condition that their distance is less than 0.2 ; this threshold value was calculated by Monte-Carlo permutation simulation (Guiot, 1990).

All ordination analyses were implemented by the CANOCO program for Windows 4.0 (Ter Braak and Smilauer, 1998). MAT analyses were performed using the ANALOG (Schweitzer, 1994) and PPPbase (Guiot and Goeury, 1996) software.

\section{Modern pollen/vegetation/pastoral activities relationships}

The three first axes, all found significant $(P<0.001$ after 999 permutations), captures $29.5 \%$ of the total variance of the data (ie, $17.9 \%, 6.9 \%$ and $5.4 \%$, respectively). The first RDA axis contrasts open with forested landscapes (Figure 5), ie, open land such as encroached heathland ( $r=-0.42$; usually treeless dry heathland) with the wooded sites from open beech forest, semi-open beech forest and dense beech forest $(r=0.47$; more or less forest found on northern slopes). The second RDA axis 2 seems to represent a soil richness gradient; it contrasts overtrampled vegetation on nitrophilous, organic and carbonated soils (loss on ignition $r=0.40$ and total $\mathrm{N} r=0.36$ ) with semi-open oak forest on relatively poor soils $(r=-0.37)$. The third RDA axis appears to best express contrasts in grazing pressure (trampling and grazing, $r=$ 0.46 and 0.43 , respectively), with sites intensively grazed and trampled on the positive side of the axis. The overgrazed community is strongly linked with axis $3(r=0.50)$ and pastoral environmental characteristics, while communities encroached heathland and semi-open oak forest are negatively correlated with axis 3 and related to low grazing pressure.

In the ordination diagram (Figure $5 \mathrm{a}, \mathrm{b}$ ), axis 1 contrasts Poaceae (open sites; negative values) with Fagus, Pinus and Quercus tot (forested sites of the northern slopes; positive values). Rumex spp., Plantago spp., Rumex obtusifolius, Plantago lanceolata, Plantago media, Chenopodiaceae, and Artemisia are also positively linked to axis 1 . These taxa appear to be related to the north aspect, which is also the preferential aspect of forested sites. All these taxa are negatively correlated with vegetation types induced by pastoral characteristics such as trampling and grazing (Figure $5 \mathrm{~b}$ ). Therefore, they cannot be considered as favoured by grazing in this crystalline bedrock area of the Iraty Mountains.

Figure 5a shows that Calluna and Rumex acetosa/acetosella and, to a lesser extent, Urtica dioica are clearly linked with soil richness, which is not the case for Rubiaceae cf. Galium and Potentilla type. Rubiaceae cf. Galium, Cichorioideae, Stellaria type, Ranunculaceae, Cirsium type, Asteroideae and, to a lesser extent, Potentilla type are related to grazing pressure, ie, to the explanatory variable of RDA axis 3 (Figure 5b). Potentilla type presents an ubiquitous behaviour; this taxon is related to open vegetation, poor soils and grazing. The latter implies a short herb stratum, which may favour growing and expansion of Potentilla species.

\section{Local Pastoral Pollen Indicators (LPPI) versus Regional Human Activities Pollen Indicators (RHAPI)}

In a previous study (Mazier et al., 2006), Davis indices (Davis, 1984) (association, under-representation and over-representation) were calculated using presence-absence data of a plant taxon in a $100 \mathrm{~m}^{2}$ vegetation survey and the taxon's pollen in a moss-polster sample (see above for more details on the methods). The results can be summarized as follows: 


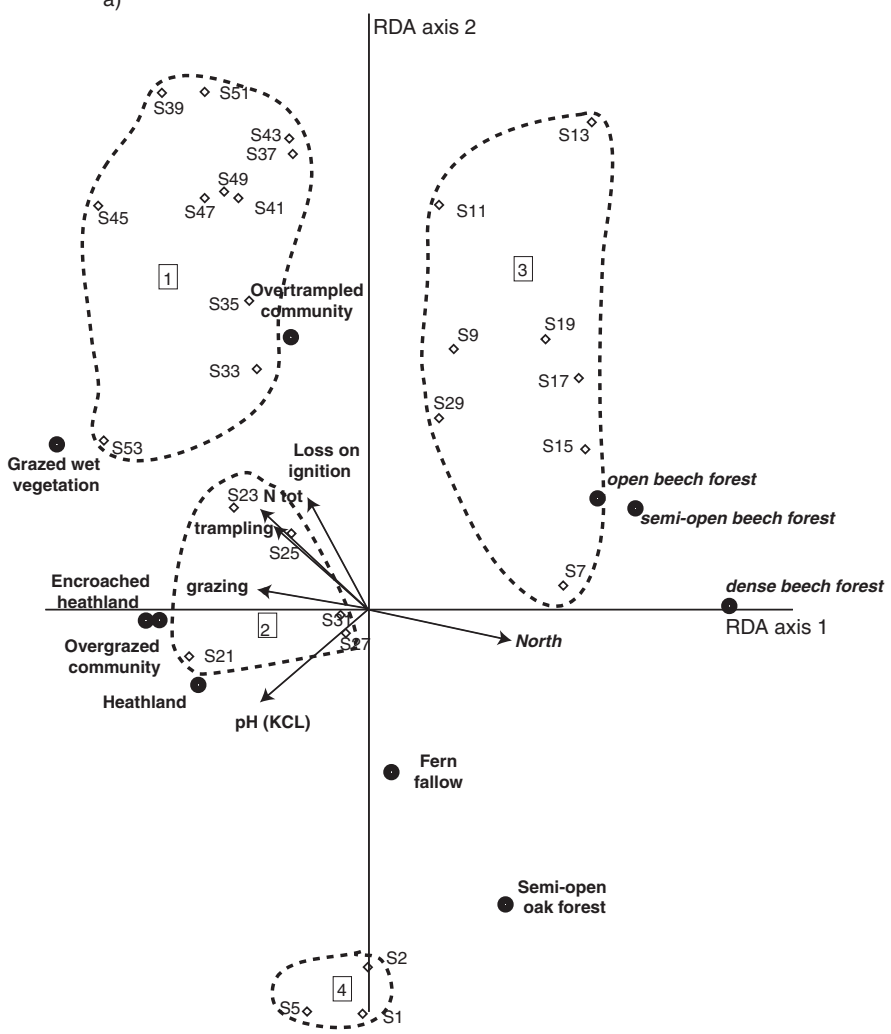

b)

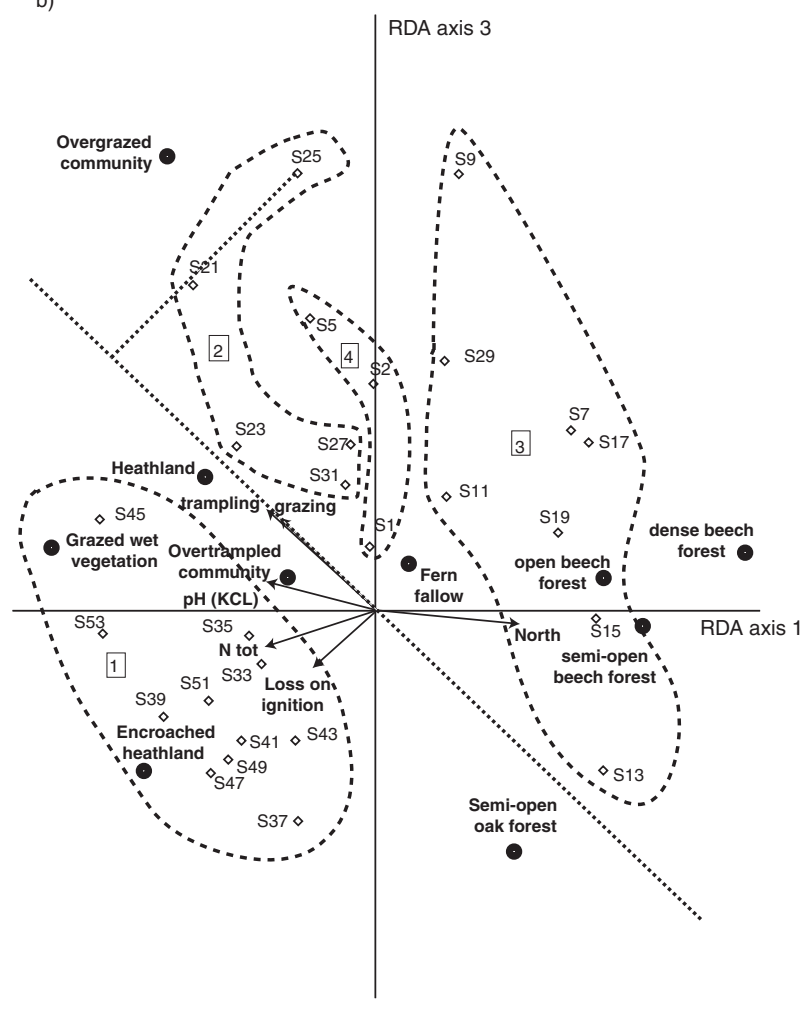

Figure 6 Plot of the 27 Sourzay fossil pollen samples (open diamonds) positioned as 'passive' samples on the RDA axes with explanatory variables (nominal variables are given with their centroïds (solid circles) and quantitative variables with solid arrows) and four passive variables (italic). Numbers (eg, S53) correspond to the depth of the samples. Clusters of sample scores (1-4) have been delimited by eye and are joined in stratigraphical order. These clusters are described in terms of sample numbers, reconstructed land use and landscape in the text. Note the shift S27-S29S31 between cluster 2 and 3. (a) Fossil samples and environmental variables on RDA axes 1 and 2. (b) Fossil samples and environmental variables on RDA axes 1 and 3. Fossil samples are projected onto the arrow of the grazing pressure variable to provide a relative degree of grazing pressure

(1) Asteroideae, Cichorioideae, Cirsium type, Rubiaceae cf. Galium, Ranunculaceae, Stellaria type and Potentilla type indicate a very local presence of the corresponding plants. Therefore, we propose in this paper to term these taxa Local Pastoral Pollen Indicators (LPPI); their occurrence in fossil pollen assemblages from the same region is assumed to indicate local grazing activities in the vicinity of the fossil pollen site, in our case the Sourzay peat bog.

(2) Four taxa were never found in the vegetation, eg, Secale, Cerealia indiff., Chenopodiaceae and Artemisia. Two taxa, Plantago lanceolata and Urtica dioica, were over-represented in the modern pollen data. Plantago lanceolata was mainly found in pollen assemblages of forested sites with aspects $\mathrm{N}$ and NW. When low pollen values are registered, Urtica dioica can't be considered as a strict pastoral indicator. Plantago media/major was never registered both in vegetation and pollen assemblages. Rumex spp., Rumex obtusifolius type and Rumex actesosa/acetosella were rarely found in both data. These ten taxa, commonly used as indicators of human activities (Behre, 1981), do not originate from local pastures in our area (Figure $5 \mathrm{~b}$ ). Their presence is mostly related to the prevailing wind which brings pollen from the wider landscape, outside the investigated area. They do not represent a specific land use but can be defined as 'Regional Human Activities Pollen Indicators' (RHAPI). Therefore, they are also assumed to represent regional human activities in fossil pollen records.

On the basis of the Davis indices, we propose that the LPPI and RHAPI can be used to infer the past local pastoral activities and the background human activities, respectively and, therefore, to assess more precisely the spatial scale of various past land uses as interpreted from fossil pollen data.

\section{Application of the modern analogue approach to the interpretation of fossil pollen data}

The fossil samples, used to reconstruct past land use, have probably a small pollen source area, since they come from a small peat bog (less than 2 ha) with a restricted catchment area (Jacobson and Bradshaw, 1981; Sugita, 1993, 1994). Moreover, we know from historical sources that grazing was the main land use in the Iraty mountainous area (Legaz, 2005). Therefore, we regard the modern pollen data set as appropriate to provide reliable information for reconstruction of local pastoral activities from the fossil pollen sequence of Sourzay.

RDA reconstruction and best modern analogues (MAT) as an aid in the interpretation of fossil pollen data The position of the fossil pollen samples from the Sourzay peat bog on the first three RDA axes (correlated to degree of openness, soil richness and grazing pressure, respectively) and their relation to modern pollen spectra and relevant variables (eg, vegetation types) provide information on environmental characteristics and past land uses around the pollen site for the last two millennia (Figure 6a, b). Moreover, the projection of fossil samples onto the arrow of the grazing pressure variable (RDA axis 1-3) provides a relative degree (a value on the axis) of grazing pressure for the fossil samples (Figure 6b). These values can be used to assess relative changes in grazing pressure and, in turn, 
a)

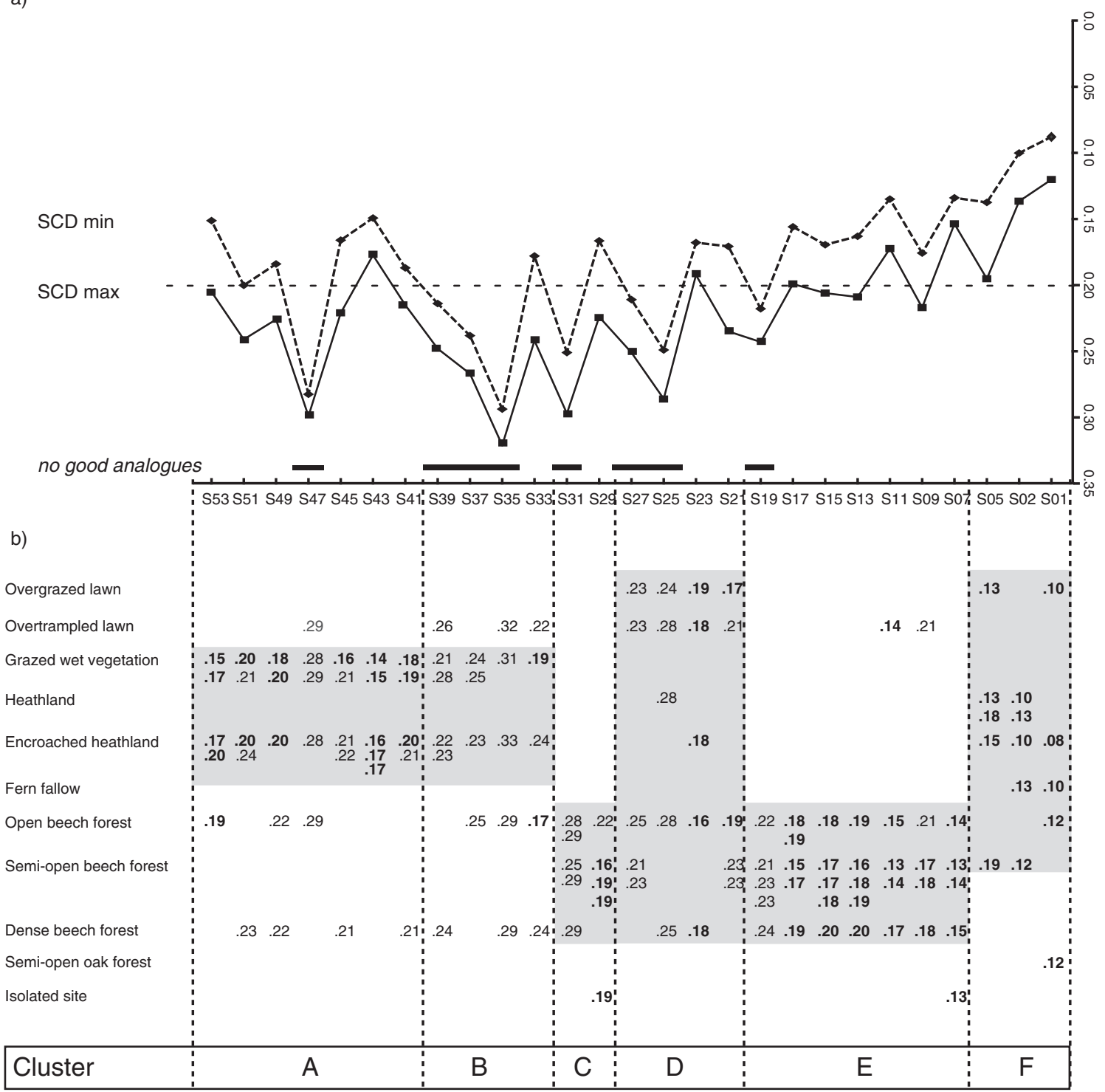

Figure 7 Modern analogue technique (MAT) with identification of the best modern vegetation type analogues for each fossil pollen sample. A fossil pollen sample (eg, S53) is compared with modern pollen samples, collected from 13 vegetation types. A dissimilarity index based on squared chord distance (SCD) is calculated between each fossil pollen sample and modern pollen samples, where 0 indicates exact similarity and higher values indicate increasing dissimilarity. (a) $\mathrm{SCD}_{\min }$ (doted line) is the distance between the closest modern analogue and the fossil sample and $\mathrm{SCD}_{\max }$ (solid line) between the lowest modern analogue and the fossil sample. When both $\mathrm{SCD}_{\min }$ and $\mathrm{SCD}_{\max }$ are more than 0.2 (threshold value), no good modern analogues were identified. (b) Relevant corresponding vegetation types of the five most similar modern pollen spectra for each fossil pollen sample and their squared distance values identified. Because modern pollen samples from grazed wet vegetation and encroached heathland are compositionally the most similar (ie, it has the lowest SCD), fossil pollen sample S53 is inferred to have originated from open wet pastureland. Clusters of samples (A-F) have been delimited based on the main vegetation types identified by MAT

of local pastoral activities through the last two millennia (see Figure 8).

MAT and square chord distances (SCD) (Figure 7a, b) show that no good analogues $\left(\mathrm{SCD}_{\min }\right.$ and $\left.\mathrm{SCD}_{\max }<0.2\right)$ were found for samples $47,39,37,35,31,27,25$ and 19 . Therefore, there are no modern pollen assemblages and corresponding vegetation types available to interpret these fossil pollen assemblages using the comparative approach. It implies that interpretation of the fossil pollen data from those stratigraphical levels should be considered with care.

A tentative interpretation of the sequence, based on both RDA and MAT, is as follows:

(1) Sample numbers 53-33: open wet pastureland on rich soils; relatively low pastoral activities (eg, trampling and grazing pressure). The fossil pollen samples are related to two main vegetation types: grazed wet vegetation and encroached heathland. The first type indicates rich and wet soil conditions and the second type suggests that the surroundings of the bog were used as extensive pastureland with relatively low grazing pressure. Within this group, some discrepancies in terms of grazing pressure can be observed. RDA axis 3 contrasts samples linked to relatively low grazing pressure (samples 49-47 and 43-37) with samples clearly related to high grazing pressure (sample 45). The lack of modern analogues for samples 39-35 may indicate a transition phase from relatively wet soils to drier conditions and from extensive to abandoned pastureland (see below). This interpretation seems reasonable as sample 33 is matched with modern pollen assemblages from grazed wetland and open beech forest. Therefore, samples 39-33 could be grouped into one 'transition' subzone.

(2) Sample numbers 31-29: increase in grazing pressure and colonization by trees. The methods give different results for 


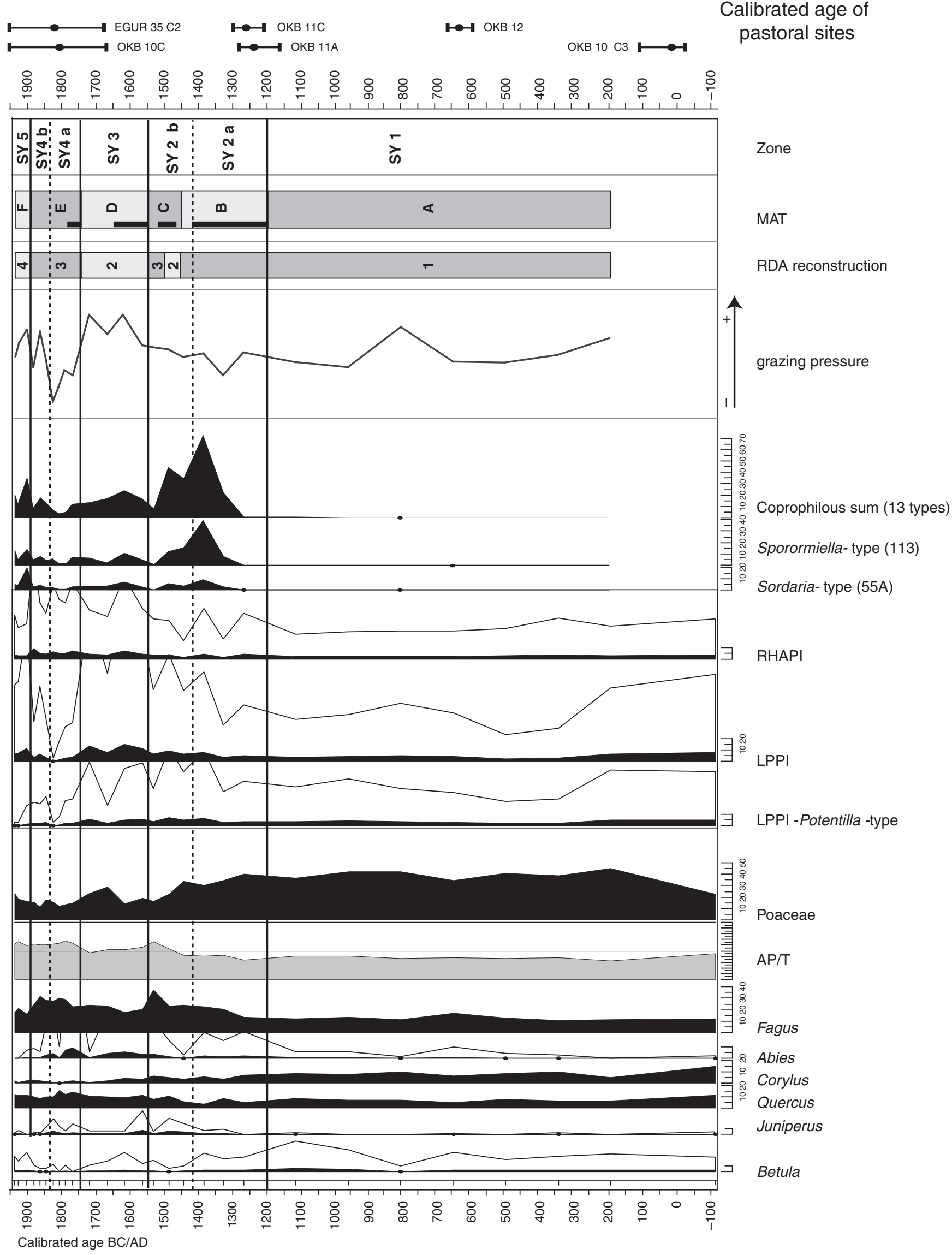

Figure 8 Synthetic figure with selected pollen and non-pollen palynomorphs taxa. Local Pastoral Pollen Indicators (LPPI with/without Potentilla type), Regional Human Activities Pollen Indicators (RHAPI) and coprophilous sum are shown. Results from RDA reconstructions and best modern analogues are presented. The grazing pressure has been estimated by projecting fossil samples onto the arrow of the explanatory grazing variable in the correlative model (Figure 6b). Cluster numbers of samples scores from RDA reconstruction (Figure 6), MAT (Figure 7) and no good modern analogues (thick line) (Figure 7a) are indicated. Dated archaeological sites are mentioned and are located on Figure 1. Zones (SY1-SY5) have been delimited according to the compilation of different proxies, see text for more explanation 
these two samples. The MAT results imply a decrease in management intensity of the pastureland and overgrowing by pioneer trees (Corylus, Fagus). The modern pollen assemblages matching with sample 29 are from semi-open beech forests. No modern analogues have been found for sample 31 . In contrast, the RDA analysis indicates an increase in grazing pressure in an open landscape (sample 31) and a forested environment (sample 29).

(3) Sample numbers 27-21: forested landscape and increasing human activity. The analyses suggest that the surroundings were characterized by a mixture of more or less wooded vegetation, and by grazing and trampling activities. Within this period, grazing pressure is inferred as being higher than earlier (RDA), but pressure seems to vary between samples (Figure 6b). This heterogeneous group of samples is related to different modern vegetation communities, mostly overgrazed and overtrampled communities and open, semi-open and dense forests (Figure 7b). There are no good modern analogues for the beginning of this phase (samples 27-25), which could be due to the lack of data from grazed forest and mixed forest with beech, fir and oak in the modern data base.

(4) Sample numbers 19-7: forested phase with little pastoral activity. These samples are related to rather rich soils and varying grazing and trampling activities. The pollen assemblages indicate that the surroundings of the peat bog were clearly more forested than during the previous and following periods (except for period 2) (Figures 6 and 7b). The projection of the fossil samples on the RDA axis 3 shows a clear gradient in the grazing pressure within the group of samples (Figure 6b). A decrease in the grazing pressure is observed from samples 19 to 13, while samples 11 to 7 again show higher pressure, with the highest pressure indicated by sample 9 .

(5) Sample numbers 5, 2 and 1: open pasture, mosaic landscape. This group of samples is related to heathland communities, fern fallow, overgrazed lawn and semi-open beech forest, which suggest a mosaic landscape comparable with that existing today around the bog. The pollen assemblages indicate poor soils, as well as grazing and trampling activities. A peak in pastoral activities is registered for sample 5 followed by a decrease in grazing pressure (Figure $6 \mathrm{~b}$ and Figure 8).

\section{Local Pastoral Pollen Indicators (LPPI) versus}

Regional Human Activities Pollen Indicators (RHAPI) Percentages curves of total LPPI and RHAPI are presented in Figure 8. Temporal differences between the two curves are assumed to be due to different land uses between the two spatial scales represented by LPPI and RHAPI respectively, ie, between the surroundings of the Sourzay peat bog and the areas outside its watershed. At AD 350-450, 1500-1550, 1750-1850, and $c$. AD 1870 there are decreases in the LPPI curve that do not correspond to any significant changes in the RHAPI curve (except at AD 1870, an increase of RHAPI to their highest values). This might indicate that, during those times, local pastoral activities decreased around the Sourzay bog, whereas regional human activities remained more or less identical (or increased at AD 1870) outside the studied watershed. At AD 1330-1380, $c$. $\mathrm{AD} 1720$, and $\mathrm{AD}$ 1920-2000, LPPI increases to higher values than earlier, while RHAPI keeps comparable values or decreases (AD 1920-2000). In those cases, local pastoral activities seem to have increased around the Sourzay bog, whereas regional human activities remained more or less identical (or decreased, AD 1920-2000) outside the studied watershed. LPPI and RHAPI reach their highest values at the same time, $c$. AD 1620 , a period of possible maximum human impact both regionally and locally.

\section{Synthesis - the use of a multidisciplinary approach to reconstruct past human impact and land-use changes}

The combination of different proxies (pollen and non-pollen palynomorphs), different methods of vegetation reconstruction inferred from pollen (RDA reconstruction, Modern analogue technique), and information from historical texts, archaeological remains (transhumant sites, Figure 1 and Table 1) and ethnoarchaeological data (Rendu, 2003) provide a useful tool for reconstruction of the nature and intensity of pastoral activities at the scale of Sourzay's watershed (Figure 8). Using all information at hand, the history of human impact and pastoral activities during the last 2000 years can be described as follows.

\section{First century BC-AD 1200 (SY-1): open wet pastureland - extensive grazing}

During this period, pollen assemblages and numerical analysis indicate that the surroundings of the peat bog were characterized by a mosaic landscape comprising encroached heathland and wet grazed vegetation communities. Both the LPPI and RHAPI curves suggest local and regional human activities. Comparison with the archaeological data leads to the differentiation of three subzones:

(1) $100 \mathrm{BC}$ to $\mathrm{AD} 250$ : the vicinity of the peat bog seems to be weakly used, implying a regular and/or seasonal occupation. The pastoral system was extensive and probably nomad with a small number of cattle. Outside the studied watershed, presence of humans and domesticated animals is attested with a dated shepherd hut (OKB 10 C3) situated on the mountains crest. Pastoral activities were attested during earlier periods by the occupation of cave sites during the Neolithic period (Marembert, 2000; Lopez-Saez et al., 2007), settlement remains dated to the Bronze Age (Galop et al., 2004; Carozza et al., 2005), and burial monuments of the Bronze and Iron Age (Blot, 1995). The Antiquity is poorly documented and our knowledge, for this region, depends on organic matter levels and cattle dung deposits found in the cave site of Mikelauen-ziloa ( $2 \mathrm{~km}$ to the northwest of the study area) (Marembert, 2000) and on our pollen record indicating human activities (RHAPI and LPPI).

(2) $\mathrm{AD} 250$ to 550: decrease in local pastoral activities (RDA reconstructions, curves of LPPI and grazing pressure).

(3) $\mathrm{AD} 550$ to 1200: increase in the local pastoral activity (LPPI). Human activities seem to be stable (RHAPI) and are attested by a dated shepherd hut (OKB 12) situated on the mountains crest.

\section{AD 1200-1550 (SY2): transition period - increase in grazing pressure and colonization of the pasturelands by trees}

This period corresponds to a transition phase from wet to dry peat bog conditions and from intensive use of the surrounding pastureland to their abandonment, as suggested by the biological, historical and archaeological data and also by the lack of good modern pollen analogues, which have been used to identify the beginning of this transition period at AD 1200. According to the available information, the period can be subdivided into two subzones: (1) local drier conditions on the bog and intensive pastoral activities, and (2) abandoned pasturelands and overgrowth by trees.

(1) AD 1200-1425. The drying-out of the peat bog is interpreted from the loss or decline of hygrophyte plant taxa and an increase of Cyperaceae at the beginning of the thirteenth century. Local pas- 
toral activities increase simultaneously with the regional human activity (increase of LPPI and RHAPI signals) during the thirteenth century. According to written sources there was at that time competition between two main abbeys (Roncevaux and Leyre) for the pannage in the mountains and the transhumance routes to access this region (Miranda, 1993; Fortun, 1994). Archaeological structures (OKB 11,11A) with livestock enclosures are attested on the mountain crests and may indicate a new pastoral system (Galop et al., 2004; Carozza et al., 2005). The overall information suggests a change from an extensive to an intensive pastoral system, involving a larger number of animals and modification of pastoral practices. The fourteenth century corresponds to a general increase of local pastoral activities (increase of LPPI and peak values in coprophilous fungi). However, there is an indication of a decrease in local and regional human activities at the beginning of the fourteenth century (decline of the LPPI and RHAPI, and increase of tree and shrub pollen taxa, eg, Fagus and Juniperus). The decline of human activities for the two spatial scales could be linked to a demographic and socio-economic crisis (plague recorded in $\mathrm{AD} 1348-1362$ ). Historical texts mention that the populations of the mountains were highly affected, which induced the abandonment of pastoral and forest activities (Goyhenetche, 1998; Legaz, 2005).

(2) AD 1425-1550. This period is characterized by the instability of local land use with a general decrease of local grazing activities (well registered by coprophilous fungi). At the beginning of the fifteenth century, indicators of human activities decrease both locally and regionally, which could be a consequence of the demographic crisis related to the plague and attested by census in 1412 (Legaz, 2005). Differences in land-use management occurred between the study area and the overall region at the beginning of the sixteenth century. Local reforestation around the peat bog followed the decline in pastoral activities (increase of beech and fir pollen and abrupt decrease of both LPPI and coprophilous fungi), whereas expansion of regional human activities is attested by historical texts (Goyhenetche, 1998; Legaz, 2005) and the increase of RHAPI. The studied watershed became probably isolated from the main pastoral areas (Artxilondo, Occabé, see Figure 1), and was probably not used in the first period of the pastoral expansion. The use of the study area might have been restricted to the edge of the forest, and linked to a sylvopastoral system.

\section{AD 1550-1750 (SY3): grazed forests?}

This period is characterized by a recovery of both local pastoral and regional human activities (increase of LPPI, coprophilous fungi and RHAPI). The landscape around the peat bog may have been characterized by a mosaic of forest, pasture and heathland patches. Historical texts indicate deforestation and the creation of new agro-pastoral areas in adjacent valleys (Legaz, 2005). As a consequence of the attested general increase in grazing pressure, the direct surroundings of the peat bog were probably again used for pastoral and forest activities. The increase in Pteridium and Calluna probably represents the development of heathland that might have been similar to that observed today. Their maintenance might have been ensured through regular burning (Métailié, 1981). A decrease in both regional and local human activities is observed around AD 1650 (decrease of LPPI, RHAPI, coprophilous fungi, eg, Sporormiella type, grazing pressure and increase of Fagus).

\section{AD 1750-1875 (SY4): forest regeneration, few pastoral activities}

This period corresponds to constant regional human activity outside the studied watershed in contrast to a general decrease of pastoral activities around the peat bog. Fluctuations in all indicators of local pastoral activities are interpreted as variable grazing pressure during this time. Two distinct periods can be identified, (1) local forest regeneration and (2) re-expansion of local grazing activities.

(1) AD 1750-c. 1825. This period corresponds to a clear decrease in pastoral activities around the peat bog, while human activity in the region is becoming stronger (decline of all indicators of local pastoral activities and increase of RHAPI). This is confirmed by the dated archaeological sites (EGURG 35 and $\mathrm{OKB} 10 \mathrm{C}$ ) discovered on the main pastoral areas outside the studied watershed. The land-use management of the watershed seems to be similar to that of the fifteenth century. This would confirm our hypothesis that the watershed might have been used as a marginal area, its use being dependent on the degree of grazing pressure in the main pastoral areas. The temporary abandonment of the watershed as grazing land favoured the expansion of Fagus, Abies and Juniperus. This phase of regeneration, with a maximum in the beginning of the nineteenth century, is reflected in the actual structure of forest edges (Métailié and Le Caro, 2000). This is also confirmed by dendrochronological measurements that revealed two distinct beech populations, respectively dated to 160-200 (SY4) and 245-350 (SY3) years old (Mougin, 2002). The two populations are linked to regeneration phases induced by declines in local pastoral activities and recorded by pollen and non-pollen palynomorphs data as well. The origins of the last regeneration phase can also be deduced from historical texts (Brocas and Legaz, 2005) and different explanations are proposed: this zone might have been declared as a no man's land because of troubles between France and Spain linked to the border delimitation (de Arvizu, 1992). The area might also have been influenced by the competition between pastoral and forest activities as forests were exploited for charcoal and tree production. However, it is most probable that the watershed was considered as a marginal area, only used when grazing pressure was too high to be supported by the main pastoral areas. When grazing pressure decreased, the study area would have been one of the first abandoned areas. A comparable land-use management is practiced today.

(2) AD c. 1825-c. 1875. A new expansion of local grazing activities and the maintenance of regional human activities are recorded by all biological data.

\section{The last century (SY-5): expansion of grazing pressure, open pastureland}

The last century corresponds to a clear increase in local pastoral activities characterized by variable grazing pressure recorded by all indicators of local pastoral activities. This new expansion of main pastureland area is also reflected by a decrease in Fagus and Abies. Texts from the forest office mention a pastoral site in 1905 close to the one occurring in the watershed. These texts also mention an overexploitation of fir (Abies) wood in this area, which resulted in the disappearance of the species in the forest. The decrease in RHAPI at the beginning of the twentieth century suggests a general decline of regional human activities, and corresponds to the known agro-pastoral decrease in the Basque country.

\section{Discussion}

\section{Potentials and limits of the modern analogue approach as an aid to the interpretation of fossil pollen data}

The modern analogue approach was applied in this study to distinguish different vegetation types using surface pollen samples from 
moss polsters in the Iraty Mountains. Multivariate techniques provided more precise information on the vegetation units present than a traditional indicator species approach (eg, Behre, 1981). It allowed to clearly identify periods characterized by wooded, opened, grazed and nitrophilous vegetation types. The correlative model also led to the identification of two distinct groups of pollen indicators characteristics of two different spatial scales, ie, the 'Local Pastoral Pollen Indicators' (LPPI), and the 'Regional Human Activities Pollen Indicators' (RHAPI). These two groups could be used to effectively distinguish between the local pastoral activities in the studied watershed scale from the 'background' human activities at a wider regional spatial scale. This distinction was impossible on the basis of traditional human-impact indicators. The variations in LPPI during the last two millennia indicate dynamic patterns of local land use/pastoral activities such as abandonment and reclaiming in the watershed. These changes were shown not to be necessarily synchronous with similar changes in human activities in the region.

This study confirms that the classical indicator species approach to reconstruct human impact and past cultural landscapes (Behre, 1981 ) is not fully appropriate for reconstructing human activities in southern mountainous areas (Galop, 1998; Galop et al., 2003). The comparative approach was applied in different countries and regions (Gaillard et al., 1992; Oeggl, 1994; Hicks and Birks, 1996; Hjelle, 1998, 1999b; Räsänen, 2001; Court-Picon et al., 2005, 2006). These investigations show some discrepancies in pollen pastoral indicators between study areas (Mazier et al., 2006). The discrepancies can be explained by differences in geology, edaphic characteristics, altitude, temperature, wind directions, agro-pastoral practices and, possibly, differences in pollen dispersal and productivity. Our study indicates that the interpretation of pollen diagrams from highland areas in terms of vegetation and land-use changes requires detailed knowledge of local pollen/vegetation characteristics of traditional managed areas.

In the patchy landscape of the Iraty Mountains, where variations in geomorphology, soil moisture and vegetation occur over small distances, opportunities for pastoral activities can be fragmented and restricted to specific areas. Small peat bogs can sense the small scale and mosaic of such activity in a mountainous environment (Davies and Tipping, 2004), as documented in the modern vegetation mosaic of the studied area (Mazier et al., 2006). Moreover the small catchment of our selected peat bog renders it sensitive to the adjacent plant communities, to local small-scale events and anthropogenic interference. The use of statistical methods, including multivariate analyses and modern analogue techniques (MAT), is dependent on the spatial scale of the training sets of modern vegetation and pollen data (Prentice, 1988; Jackson and Williams, 2004; Sugita, 2007a). The moss polsters used to collect the modern pollen data and the peat bog from which the fossil pollen record was extracted should, theoretically, both be characterized by a small pollen source area. Therefore, we assumed that the modern pollen assemblages from moss polsters could be accurately compared with the fossil pollen assemblages, which is partly confirmed by the relatively large number of good analogues that were found.

RDA and MAT applied to the pollen sequence from Sourzay provided comparable results. RDA offers more detailed information on the intensity of grazing pressure and its variation through time and on the possible mixtures/mosaics of various vegetation types within the study area with a more precise assessment of the relative importance of different vegetation units (extensive pastureland, overgrazed vegetation, open or closed forest, nitrophilous vegetation, etc.). Our study suggests that the upland area consisted of a spatially variable, dynamic mosaic of clearly differentiated plant communities through the last two millennia. MAT identifies the most probable vegetation types represented by the fossil pollen assemblages, and provides new insights on the prevailing land use in the catchment area. It also showed that some fossil samples did not have any good analogue in the modern pollen data set and, therefore, could not be ascribed to a specific vegetation type, which can be an indication that the past communities are no longer found today in the study area, and/or that the overall mosaic of different vegetation types was different in terms of spatial distribution. Modern analogues are missing for mixed and grazed forest, overgrown vegetation (including different stages of succession in previously grazed pastures) and transition phases of peat bog dynamics. There are grazed beech forests today outside the studied watershed in the same crystalline bedrock, but grazed mixed forest with beech (Fagus) and fir (Abies) do not exist. Whether our modern data set can be improved in this respect is unclear, as mixed forests disappeared from the crystalline bedrock sometime during the nineteenth century. This is one of the most serious limitations of the modern analogue approach in this study.

The modern analogue approach clearly helped to interpret the fossil pollen record in terms of local pastoral land management and regional human activities. The inferred past vegetation and land use suggests that the studied upland area was far from uniformly used or unproductive in pastoral terms, but was characterized by significant dynamics in space and time.

\section{Coprophilous fungi and Local Pastoral Pollen Indicators}

One of the study aims was to compare, in the same fossil sequence, two independent proxy records of local pastoral activities: coprophilous fungi and Local Pastoral Pollen Indicators (LPPI).

Spores of Sporormiella were recorded by Davis (1987) and Davis and Turner (1986), who concluded that these spores can be used as indicators of the occurrence of herbivore populations. Van Geel et al. (2007) suggest that the complete spectrum of spores from the various coprophilous fungal taxa can be a powerful indicator of the former presence of dung produced by herbivores.

In our study, the coprophilous fungi helped us to confirm the interpretations based on the pollen data. In particular, Sordaria type and Sporormiella type are very closely related to the Local Pastoral Pollen Indicators curve. The two proxies, LPPI and coprophilous fungi, show the same trends and seem to react simultaneously to a decrease or an increase in grazing pressure. Moreover, the comparison of LPPI, coprophilous fungi, and Potentilla type curves tends to show that Potentilla type, usually considered as an ubiquist taxon, seems to be related to changes in grazing pressure. Therefore, in this case, the inclusion of this taxon in the LPPI is justified. These two proxies were very useful in combination for the type of questions studied in this investigation, ie, the identification of the spatial dimension and intensity of local pastoral activities. NPP also confirmed the validity of the pastoral pollen indicators defined on the basis of modern pollen-vegetation relationships in the area.

The exact spatial scales of vegetation represented by the pollen in the moss polsters and by the pollen record from the Souzay bog are still not known. Estimation of the relevant source area (RSAP) sensu Sugita (1994) in a study in progress will improve our understanding of the spatial scale of the vegetation and land-use reconstruction. Moreover, a study of the modern fungal spores/vegetation/environment relationships, in progress in the same area, will lead to more precise interpretation of the fungal spores in terms of composition, presence and spatial distribution of past faunas.

\section{Conclusion}

The major aim of this study was to match modern and fossil proxies (pollen and non-pollen palynomorphs) with available archaeological and historical data in one target area, in order to reconstruct 
local pastoral activities during the last 2000 years as precisely as possible. This interdisciplinary approach is one of the first performed in the Pyrenees Mountains in order to tackle this kind of question, and it provides encouraging results.

Pollen/vegetation relationships from modern analogues of past pastoral vegetation types offers a useful tool for the interpretation of fossil pollen sequences from the same geographical area in terms of vegetation and land-use changes. Multivariate analysis (redundancy analysis including 61 sites and 13 explanatory variables) clearly separated pollen assemblages from wooded, opened, grazed and nitrophilous vegetation types. The correlative model also helped to discriminate two distinct groups of taxa, 'Local Pastoral Pollen Indicators' (LPPI) and 'Regional Human Activities Pollen Indicators' (RHAPI). RHAPI can be used to reconstruct human activities at the regional spatial scale, while LPPI, valid for this mountainous region on crystalline bedrock, estimates the extent and the nature of local pastoral activities.

RDA reconstruction and the modern analogue technique applied to fossil pollen samples offer more precise information on the relative importance of different vegetation units and on the intensity of grazing pressure and its variation through time. Modern analogues were missing for grazed and mixed forests, and for vegetation types characteristic of transition phases in peat bog dynamics, which is a limitation of the comparative approach applied in this study. The modern data set could be partly improved by sampling vegetation types outside the studied watershed in the same crystalline bedrock area.

Multiproxies of past pastoral activities combined with historical and archaeological data were used to propose a local pastoral history of the watershed for the last two millennia. All the available information reveals that, for certain time periods, differences in land-use management between the local watershed and the region outside it indicate that the surroundings of the bog represented a marginal area used when grazing pressure in the adjacent valleys and main pastoral area was too intense. It was most probably one of the first areas to be abandoned when regional human activities declined and/or when grazing pressure was such that the main pasturelands in the valleys could sustain it. The latter might be explained by the low pastoral value of such grasslands and heaths, steep slopes and the small size of the area with no good visibility over the surrounding landscape. The occurrence of pastoralism outside the watershed during periods of low activities locally is attested by dated archaeological sites.

Defining the time, duration and spatial extent of occupation would require a larger number of dated archaeological sites. Recent excavations have revealed the occurrence of shepherd huts and enclosures within the studied watershed, but they are not yet dated. Pollen profiles from a number of small peat bogs in the region would provide a better understanding of the spatial distribution of pastoral activities (D. Galop, unpublished data, 2005). The selection of several small peat bogs for pollen analysis will allow the generation of local-scale reconstructions useful to archaeologists (Davies and Tipping, 2004). Further, the application of a modelling approach will provide estimates of the relevant source area of pollen for moss polsters and fossil pollen sites such as the Sourzay peat bog, which will allow to precisely define the spatial distribution vegetation communities within a given distance around the fossil pollen sequence for different time windows (eg, Gaillard, 2007; Sugita, 2007a, b).

\section{Acknowledgements}

This paper is a contribution to the collective research programmes 'Paléoenvironnement et Archéologie pastorale' (coordinated by D. Galop and C. Rendu) sponsored by the French CNRS and the
'Paléoenvironnement et dynamiques de l'anthropisation en montagne basque' (coordinated by D. Galop) sponsored by the Ministry of Culture and SRA Aquitaine. We are grateful to the persons involved in the Swiss National Science Foundation (SNF) project NCCR Plant Survival, module PS6 'Pattern and long-term changes in pasture-woodlands: Complex interactions in a traditional type of agro-forestry' (coordinated by C. Scheidegger 2001-2005) for their advice on the integrated synusial approach and vegetation analysis. The manuscript was improved thanks to the helpful comments and suggestions from two anonymous referees.

\section{References}

Behre, K.E. 1981: The interpretation of anthropogenic indicators in pollen diagrams. Pollen et Spores 23, 225-45.

Berglund, B.E., editor 1991: The cultural landscape during 6000 years in southern Sweden - the Ystad Project. Munksgaard International.

Blackford, J.J. and Innes, J.B. 2006: Linking current environments and processes to fungal spore assemblages: surface NPM data from woodland environments. Review of Palaeobotany and Palynology 141, 179-87.

Blot, J. 1995: Contribution à l'étude des cercles de pierres en Pays Basque de France. Bulletin de la Société Préhistorique Française 92, 525-48.

Bradshaw, R.H.W. 1981: Modern pollen representation factors for woods in south-west England. Journal of Ecology 69, 45-70.

Braun-Blanquet, J. 1964: Pflanzensoziologie. Grundzüge der Vegetationskunde. Springer, $865 \mathrm{pp}$.

Brocas, D. and Legaz, A. 2005: La montagne basque: sources et ressources. Les pâturages et les bois dans les Pyrénées occidentales (XIe-XIXe s), Les ressources naturelles des Pyrénées du Moyen Age à l'époque moderne. Exploitation, gestion et appropriation. In Congrès international RESOPYR. Presses Universitaires de Perpignan, volumes 49-69.

Buurman, J., van Geel, B. and van Reenen, G.B.A. 1995: Palaeoecological investigations of a Late Bronze Age watering-place at Bovenkarspel, the Netherlands. In Herngreen, G.F.W. and van der Valk, L., editors, Neogene and Quaternary geology of north-west Europe. Mededelingen Rijks Geologische Dienst 52, 249-70.

Carozza, L., Galop, D., Marembert, F. and Monna, F. 2005: Quel statut pour les espaces de Montagnes durant l'âge du Bronze? Regards croisés sur les approches sociétés-environnement dans les Pyrénées occidentales. Documents d'Archéologie Méridionale 28, 7-23.

Court-Picon, M., Buttler, A. and de Beaulieu, J.-L. 2005: Modern pollen-vegetation relationships in the Champsaur valley (French Alps) and their potential in the interpretation of fossil pollen records of past cultural landscapes. Review of Palaeobotany and Palynology 135, 13-39.

_ 2006: Modern pollen/vegetation/land-use relationships in mountain environments: an example from the Champsaur valley (French Alps). Vegetation History and Archaeobotany 15, 151.

Davies, A.L. and Tipping, R. 2004: Sensing small-scale human activity in the palaeoecological record: fine spatial resolution pollen analyses from Glen Affric, northern Scotland. The Holocene 14, 233-45.

Davis, O.K. 1984: Pollen frequencies reflect vegetation patterns in a Great Basin (USA) mountain range. Review of Palaeobotany and Palynology 40, 295-315.

1987: Spores of the dung fungus Sporormiella: increased abundance in historic sediments and before Pleistocene Megafaunal Extinction. Quaternary Research 28, 290-94.

Davis, O.K. and Shafer, D.S. 2006: Sporormiella fungal spores, a palynological means of detecting herbivore density. Palaeogeography Palaeoclimatology, Palaeoecology 237, 40-50.

Davis, O.K. and Turner, R.M. 1986: Palynological evidence for the historic expansion of Juniper and desert shrubs in Arizona, U.S.A. Review of Palaeobotany and Palynology 49, 177-93.

de Arvizu, F. 1992: El conflicto de los Alduides (Pirineo navarro), Gobierno de Navarra. Pampelune, 427 pp.

Faegri, K. and Iversen, J. 1989: Textbook of pollen analysis. Wiley, $328 \mathrm{pp}$. 
Fortun, L.J. 1994: Leire, un señorio monástico en navarra (siglos IX-XIX), Gobierno de Navarra. Pampelune, 926 pp.

Gaillard, M.-J. 2007: Detecting human impact in the pollen record. In Elias, S.A., editor, Encyclopedia of Quaternary science. Elsevier, University of London, 2570-95.

Gaillard, M.-J., Birks, H.J.B., Emanuelsson, U. and Berglund, B.E. 1992: Modern pollen/land-use relationships as an aid in the reconstruction of past land-uses and cultural landscapes: an example from south Sweden. Vegetation History and Archaeobotany 1, 3-17. Gaillard, M.-J., Birks, H.J.B., Emanuelsson, U., Karlsson, S., Lageras, P. and Olausson, D. 1994: Application of modern pollen/land-use relationships to the interpretation of pollen diagrams reconstuctions of land-use history in south Sweden, 3000-0 BP. Review of Palaeobotany and Palynology 82, 47-73.

Galop, D. 1998: La forêt, l'homme et le troupeau dans les Pyrénées. 6000 ans d'histoire de l'environnement entre Garonne et Méditerranée. Contribution palynologique. GEODE - Laboratoire d'écologie terrestre - Framespa, $285 \mathrm{pp}$

Galop, D., Mazier, F., Lopez-Saez, J.-A. and Vannière, B. 2003 Palynologie et histoire des activités humaines en milieu montagnard. Bilan provisoire des recherches et nouvelles orientations méthodologiques sur le versant nord des Pyrénées. Archéologie du midi médiéval 21, 159-70.

Galop, D., Rendu, C., Barcet, H., Buttler, A., Campmajo, P., Cugny, C., Gauthier, E., Legaz, A., Lopez-Saez, J.-A., Mazier, F., Métailié, J.P., Dominique, S. and Vannière, B. 2004: Paléoenvironement et archéologie pastorale. Propositions méthodologiques pour une approche intégrée des modalités de l'anthropisation en haute montagne pyrénéenne du Néolithique à l'actuel. UMR 6565 CNRS-Université de FrancheComté, $70 \mathrm{pp}$

Gillet, F. and Gallandat, J.-D. 1996: Integrated synusial phytosociology: some notes on a new, multiscalar approach to vegetation analysis. Journal of Vegetation Science 7, 13-18.

Gillet, F., De Foucault, B. and Julve, P. 1991: La phytosociologie synusiale intégrée: objets et concepts. Candollea 46, 315-40.

Gillet, F., Besson, O. and Gobat, J.-M. 2002: PATUMOD: a compartment model of vegetation dynamics in wooded pastures. Ecological Modelling 147, 267-90.

Goyhenetche, M. 1998: Histoire générale du Pays basque. Préhistoire-Epoque romaine-Moyen-Âge. Donostia, $492 \mathrm{pp}$.

Graf, M.-T. and Chmura, G.L. 2006: Development of modern analogues for natural, mowed and grazed grasslands using pollen assemblages and coprophilous fungi. Review of Palaeobotany and Palynology 141, 139-49.

Grimm, E. 1987: CONISS: a Fortan 77 program for stratigraphically constrained cluster analysis by the method of incremental sum of squares. Computers and Geosciences 13, 13-35.

Guiot, J. 1990: Methodology of the last climatic cycle reconstruction from pollen data. Palaeogeography Palaeoclimatology Palaeoecology 80, 49-69.

Guiot, J. and Goeury, C. 1996: PPPbase, a software for statistical analysis of paleoecological data. Dendrochronologia 14, 295-300.

Hausmann, S., Lotter, A.F., van Leeuwen, J.F.N., Ohlendorf, C., Lemcke, G., Grönlund, E. and Sturm, M. 2002: Interactions of climate and land use documented in the varved sediments of Seebergsee in the Swiss Alps. The Holocene 12, 279-89.

Hicks, S. and Birks, H.J.B. 1996: Numerical analysis of modern and fossil pollen spectra as a tool for elucidating the nature of fine-scale human activities in boreal areas. Vegetation History and Archaeobotany 5, 257-72.

Hjelle, K.L. 1998: Herb pollen representation in surface moss samples from mown meadows and pastures in Western Norway. Vegetation History and Archaeobotany 7, 79-96.

1999a: Use of modern pollen samples and estimated pollen representation factors as aids in the interpretation of cultural activity in local pollen diagrams. Norwegian Archaeological Review 32, 19-39. — 1999b: Modern pollen assemblages from mown and grazed vegetation types in western Norway. Review of Palaeobotany and Palynology 107, 55-81.

Iversen, J. 1964: Plant indicators of climate, soil, and other factors during the Quaternary. Report of the VIth International Congress on Quaternary Warsaw 1961. Vol. II: Palaeobotanical Section, 421-28.

Jackson, S.T. and Williams, J.W. 2004: Modern analogs in Quaternary paleoecology: here today, gone yesterday, gone tomorrow? Annual Review of Earth and Planetary Science 32, 495-537.

Jacobson, G.L. and Bradshaw, R.H.W. 1981: The selection of sites for paleovegetational studies. Quaternary Research 16, 80-96.

Kohler, F., Gillet, F., Progin, M.-A., Gobat, J.-M. and Buttler, A. 2004: Seasonal dynamics of plant species at fine scale in wooded pastures. Community Ecology 5, 7-17.

Legaz, A. 2005: Système pastoraux et société en Basse-Navarre du XIII au XVIII siècle: construction et transitions. Unpublished $\mathrm{PhD}$ thesis, University of Toulouse 2.

Lopez-Saez, J.A., Galop, D., Iriarte, M.J. and Lopez-Merino, L. 2007: Paleoambiente y antropización en los Pirineos de Navarra durante el holoceno medio (VI-IV milenios cal. BC): una perspectiva palinológica. Veleia 24-25, 645-53.

Marembert, F. 2000: La grotte de Mikelauen-Ziloa. In Aquitaine, S., editor, Paléoenvironnement et anthropisation de la montagne Basque Ministère de la culture. CNRS, 71-81.

Mazier, F., Galop, D., Brun, C. and Buttler, A. 2006: Modern pollen assemblages from grazed vegetation in the western Pyrenees, France: a numerical tool for more precise reconstruction of past cultural landscapes. The Holocene 16, 91-103.

Métailié, J.-P. 1981: Le feu pastoral dans les Pyrénées centrales (Barousse, Oueil, Larboust). CNRS, 195 pp.

Métailié, J.-P. and Le Caro, P. 2000: Les lisières pâturées. Premiers éléments pour une analyse des dynamiques sylvo-pastorales dans les pâturages du massif d'Iraty. In Aquitaine, S., editor, Paléoenvironnement et anthropisation de la montagne Basque. Ministère de la culture CNRS, 7-13.

Miranda, G. 1993: Roncesvalles. Trayectoria patrimonial (siglos XII-XIX), Gobierno de Navarra. Pampelune, 297 pp.

Miras, Y., Laggoun-Défarge, F., Guenet, P. and Richard, H. 2004: Multi-disciplinary approach to changes in agro-pastoral activities since the Subboreal in the surroundings of the 'Narse d'Espinasse'. Vegetation History and Archaeobotany 13, 91-103.

Moore, P.D., Webb, J.A. and Collinson, M.E. 1991: Pollen analysis. Blackwell Science, $216 \mathrm{pp}$.

Mougin, V. 2002: Forêt et métallurgie en Pays basque nord. Analyses anthracologique et dendrochronologique des charbonnières du massif d'Iraty. Unpublished Masters thesis, University of Franche-Comté.

Oeggl, K. 1994: The palynological record of human impact on highland zone ecosystems. In Biagi, P. and Nandris, J., editors, Highland zone exploitation in Southern Europe. Monografie di 'Natura Bresciana' 20, $107-22$.

Olff, H. and Ritchie, M.E. 1998: Effects of herbivores on grassland plant diversity. Trends in Ecology and Evolution 13, 261-65.

Overpeck, J.T., Webb, I.T. and Prentice, I.C. 1985: Quantitative interpretation of fossil pollen spectra: dissimilarity coefficients and the method of modern analogs. Quaternary Research 23, 87-108.

Prentice, I.C. 1980: Multidimensional scaling as a research tool in Quaternary palynology: a review of theory and methods. Review of Palaeobotany and Palynology 31, 71-104.

- 1988: Records of vegetation in time and space: the principles of pollen analysis. In Huntley, B. and Webb, T., III, editors, Vegetation history. Kluwer Academic Publishers, 17-42.

Räsänen, S. 2001: Tracing and interpreting fine-scale human impact in nothern Fennoscandia with the aid of modern pollen analogues. Vegetation History and Archaeobotany 10, 211-18.

Reille, M. 1992-98: Pollen et spores d'Europe et d'Afrique du Nord. Laboratoire de Botanique Historique et Palynologiepp.

Reimer, P.J., Baillie, M.G.L., Bard, E., Bayliss, A., Beck, J.W., Bertrand, C.J.H., Blackwell, P.G., Buck, C.E., Burr, G.S., Cutler, K.B., Damon, P.E., Edwards, R.L., Fairbanks, R.G., Friedrich, M., Guilderson, T.P., Hogg, A.G., Hughen, K.A., Kromer, B., McCormac, G., Manning, S., Ramsey, C.B., Reimer, R.W., Remmele, S., Southon, J.R., Stuiver, M., Talamo, S., Taylor, F.W., van der Plicht, J. and Weyhenmeyer, C.E. 2004: IntCal04 terrestrial radiocarbon age calibration, 26-0 ka BP. Radiocarbon 46, 1029-58. Rendu, C. 2003: La montagne d'Enveig. Une estive pyrénéenne dans la longue durée. Perpignan, 606 pp. 
Rendu, C., Campmajo, P., Sordoillet, D. and Legaz, A. 2004: Archéologie du pastoralisme. In Galop, D., Rendu, C., Barcet, H., Buttler, A., Campmajo, P., Cugny, C., Gauthier, E., Legaz, A., LopezSaez, J.-A., Mazier, F., Métailié, J.-P., Dominique, S. and Vannière, B., editors, Paléoenvironement et archéologie pastorale. Propositions méthodologiques pour une approche intégrée des modalités de l'anthropisation en haute montagne pyrénéenne du Néolithique à l'actuel. UMR 6565 CNRS-Université de Franche-Comté, 36-39.

Schweitzer, P.N. 1994: ANALOG: a program for estimating paleoclimate parameters using the method of modern analogs. U.S. Geological Survey Open-file Report 94-645.

Sjögren, P. and Lamentowicz, M. 2008: Human and climatic impact on mires: a case study of Les Amburnex mire, Swiss Jura Mountains. Vegetation History and Archaeobotany 17, 185-97.

Stuiver, M., Reimer, P.J., Bard, E., Beck, J.W., Burr, G.S., Hughen, K.A., Kromer, B., McCormac, G., van der Plicht, J. and Spurk, M. 1998: Intcal98 radiocarbon age calibration, 24 000-0 cal BP. Radiocarbon 40, 1041-83.

Sugita, S. 1993: A model of pollen source area for an entire lake surface. Quaternary Research 39, 239-44.

1994: Pollen representation of vegetation in quaternary sediments: theory and method in patchy vegetation. Journal of Ecology 82, 881-97.

2007a: Theory of quantitative reconstruction of vegetation. I: pollen from large lakes REVEALS regional vegetation composition. The Holocene 17, 229-41.

2007b: Theory of quantitative reconstruction of vegetation II: all you need is LOVE. The Holocene 17, 243-57.

Telford, R.J., Heegaard, E. and Birks, H.J.B. 2004: The intercept is a poor estimate of a calibrated radiocarbon age. The Holocene 14, 296-98.
Ter Braak, C.J.F. and Prentice, C.I. 1988: A theory of gradient analysis. Advances in Ecological Research 18, 271-317.

Ter Braak, C.J.F. and Smilauer, P. 1998: CANOCO reference manual. User's guide to Canoco for Windows. Software for canonical community ordination (version 4). Centre for Biometry Wageningen, $352 \mathrm{pp}$.

van Geel, B. 1978: A palaeoecological study of Holocene peat bog section in Germany and The Netherlands, based on the analysis of pollen, spores and macro- and micro-scopic remains of fungi, algae, cormophytes and animals. Review of Palaeobotany and Palynology $25,1-120$.

van Geel, B. and Aptroot, A. 2006: Fossil ascomycetes in Quaternary deposits. Nova Hedwigia 82, 313-29.

van Geel, B., Buurman, J., Brinkkemper, O., Schelvis, J. and Aptroot, A. 2003: Environmental reconstruction of a Roman Period settlement site in Uitgeest (The Netherlands), with special reference to coprophilous fungi. Journal of Archaeological Science $30,873-83$.

van Geel, B., Zazula, G.D. and Schweger, C.E. 2007: Spores of coprophilous fungi from under the Dawson tephra $(25,30014 \mathrm{C}$ years BP), Yukon Territory, northwestern Canada. Palaeogeography Palaeoclimatology Palaeoecology 252, 481-85.

Wahl, E.R. 2004: A general framework for determining cutoff values to select pollen analogs with dissimilarity metrics in the modern analog technique. Review of Palaeobotany and Palynology 128, 263-80.

Wehrli, M., Tinner, W. and Amman, B. 2007: 16000 years of vegetation and settlement history from Egelsee (Menzingen, central Switzerland). The Holocene 17, 747-61.

Wright, H.E.J. 1967: The use of surface samples in quaternary pollen analysis. Review of Palaeobotany and Palynology 2, 321-30. 